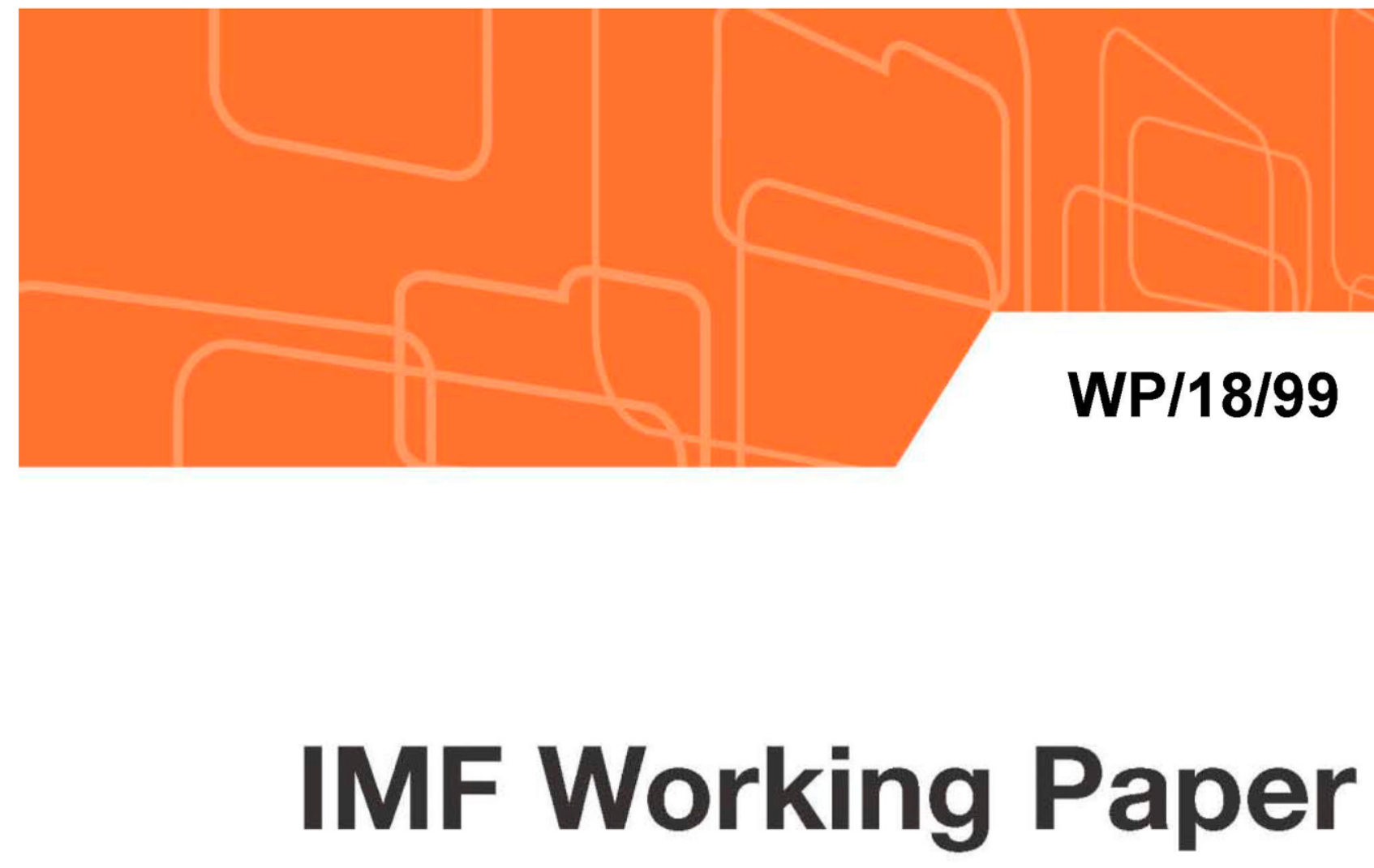

\title{
Where Have All the Profits Gone? European Bank Profitability Over the Financial Cycle
}

By Enrica Detragiache, Thierry Tressel, and Rima Turk-Ariss

IMF Working Papers describe research in progress by the author(s) and are published to elicit comments and to encourage debate. The views expressed in IMF Working Papers are those of the author(s) and do not necessarily represent the views of the IMF, its Executive Board, or IMF management. 


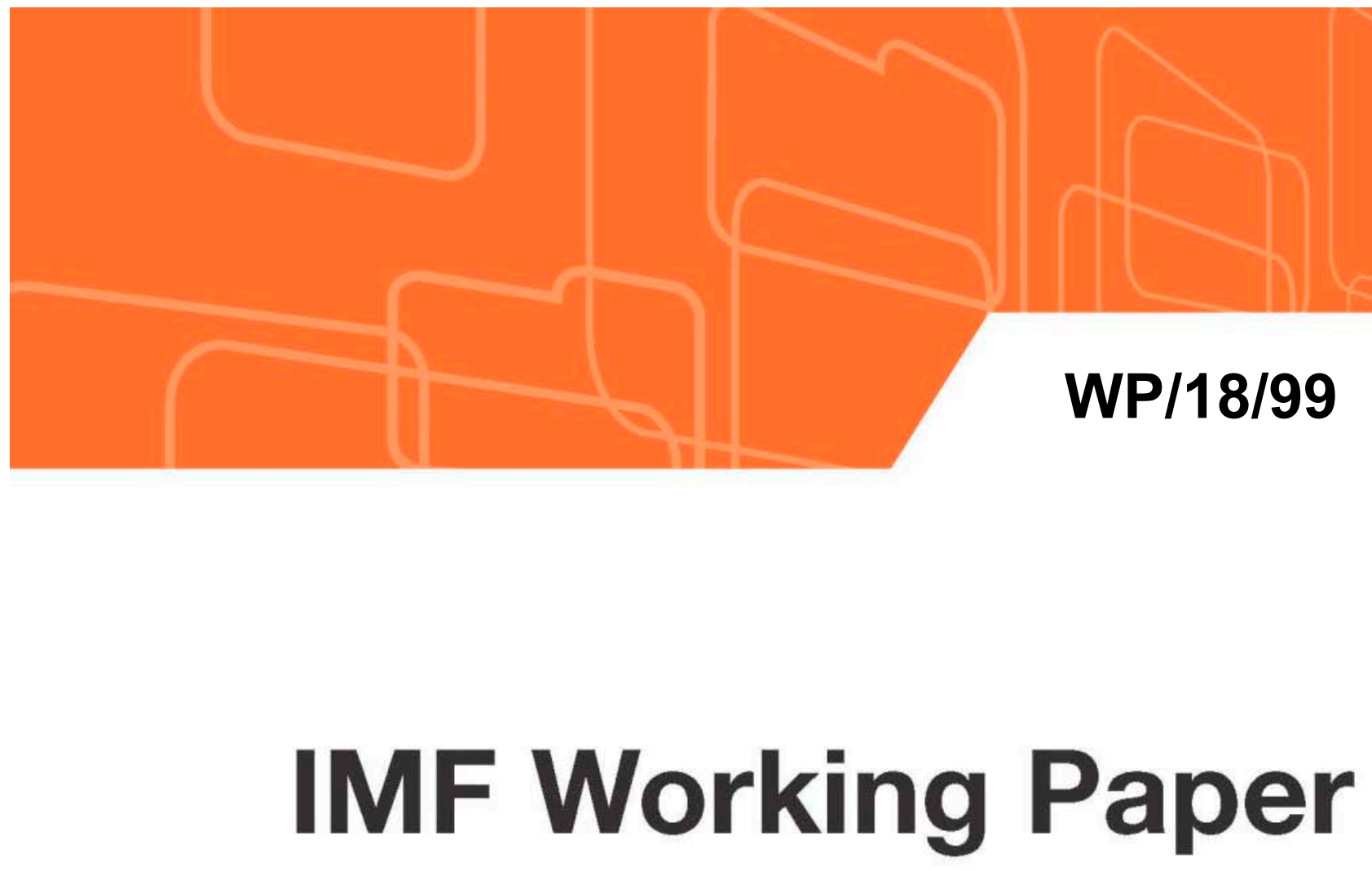

\section{Where Have All the Profits Gone? European Bank Profitability Over the Financial Cycle}

By Enrica Detragiache, Thierry Tressel, and Rima Turk-Ariss

IMF Working Papers describe research in progress by the author(s) and are published to elicit comments and to encourage debate. The views expressed in IMF Working Papers are those of the author(s) and do not necessarily represent the views of the IMF, its Executive Board, or IMF management. 


\section{Contents}

Abstract

I. Introduction $\underline{4}$

II. The Sample $\underline{5}$

III. Stylized Facts: Boom and Bust in the EU Banking Sector .............................................

IV. Decomposing the Decline in Bank Profitability .............................................................

V. Explaining Changes in Bank Profitability over the Financial Cycle ……………………....16

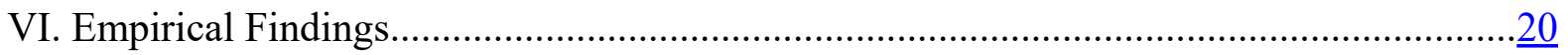

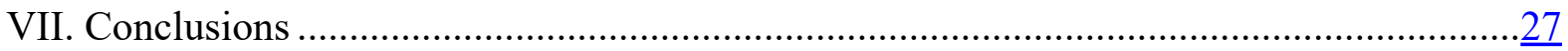

\section{Tables}

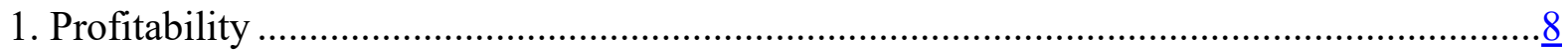

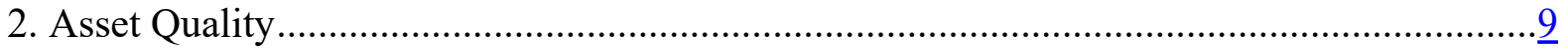

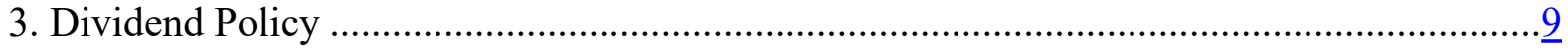

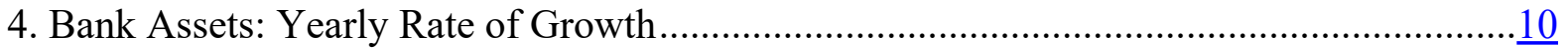

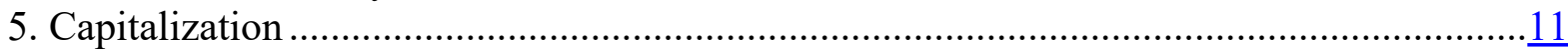

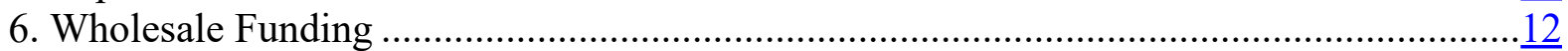

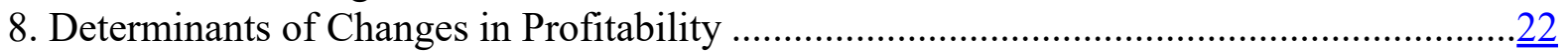

9. Bank Profitability Over the Financial Cycle: Cross-Sectional Regressions ..........................25

10. Bank Profitability Post-Crisis: Cross-Sectional Probit Regressions....................................

\section{Figures}

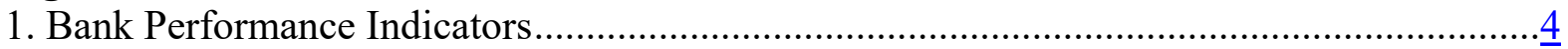

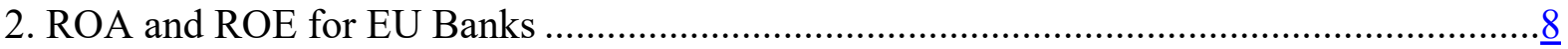

3. Change in ROA and Contribution of its Components by Region....................................14

4. Change in ROA and Contribution of its Components by Quartile ......................................

5. Change in ROA and Contribution of its Components by G-SIB Country ………….............

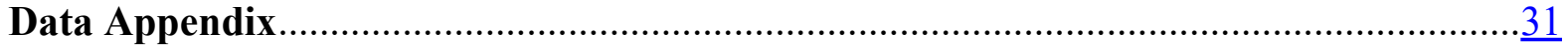

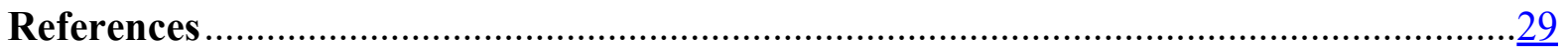




\title{
IMF Working Paper
}

European Department

\section{Where Have All the Profits Gone? European Bank Profitability over the Financial Cycle}

Prepared by Enrica Detragiache, Thierry Tressel, and Rima Turk-Ariss ${ }^{1}$

Authorized for distribution by Poul M. Thomsen

April 2018

\section{IMF Working Papers describe research in progress by the author(s) and are published to elicit comments and to encourage debate. The views expressed in IMF Working Papers are those of the author(s) and do not necessarily represent the views of the IMF, its Executive Board, or IMF management.}

\begin{abstract}
The paper investigates EU banks' profitability through the recent financial cycle using banklevel balance sheet and income statement data. We find that banks that were more successful at protecting their profits had a less pronounced deterioration in loan quality and a larger improvement in cost efficiency. They also downsized their assets more aggressively during the crisis, and reduced reliance on wholesale funding more markedly post-crisis. Net interest margins remained broadly stable over the financial cycle, including post-crisis, and there is no clear evidence that aspects of bank business model, such as higher reliance on fees and commission income, were associated with better profitability post-crisis.
\end{abstract}

JEL Classification Numbers: E30, G01, G21.

Keywords: Financial Cycle, Bank Profitability, Financial Crisis.

Author’s E-Mail Address: Edetragiache@imf.org; Ttressel@imf.org; Rturk@imf.org

\footnotetext{
${ }^{1}$ We wish to thank, without implicating, Deniz Igan, and seminar participants at the IMF and the Banque de France for very helpful comments. Morgan Maneely provided excellent research assistance.
} 


\section{INTRODUCTION}

The banking system in the European Union (EU) has gone through remarkable transition in the last 15 years or so: a rapid expansion, a deep crisis, and a tepid recovery. The recovery has been clouded by crisis legacies, the need to adapt to stricter financial regulation, increased competition from nonbank financial intermediaries, and disruption from new technologies. Adding to the list of post-crisis woes, weak economic growth and lackluster business investment have weighed on bank credit demand, while negative policy interest rates and a flat yield curve put pressure on interest margins. As a result, bank profitability, having plunged during the crisis, has remained low in the post-crisis period (Figure 1; see section II for the definition of subperiods). For listed banks, the extent of the current difficulties is also captured by the depressed market-to-book ratios observed in recent years. These low ratios - seen as indicators of low franchise value-have led some to question whether banks are safer than they were before the crisis despite their stronger capital and liquidity position (Calomiris and Nissim, 2014, Sarin and Summers, 2016).

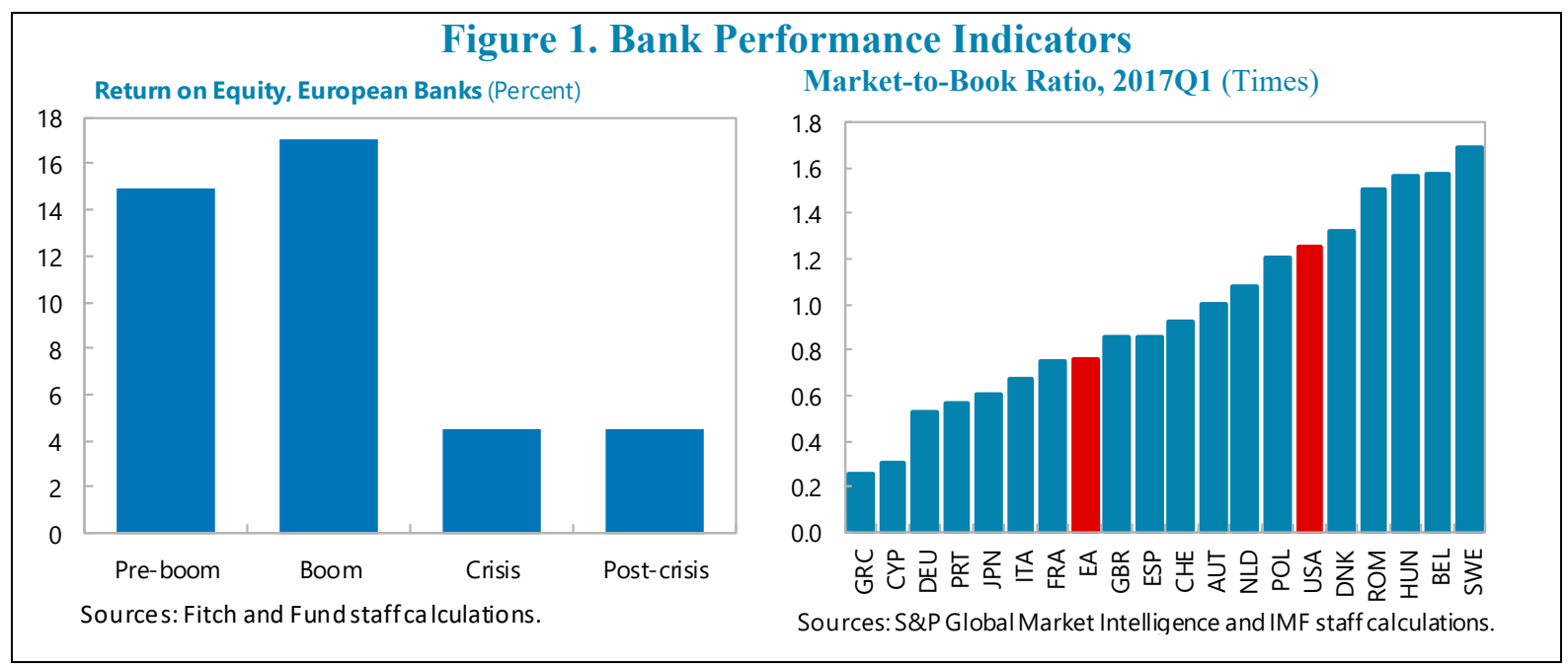

Turning to diagnoses, some (e. g., Kok, Christoffer, Móré, and Pancaro, 2015) have claimed that cyclical factors are mainly responsible for low profitability, while others have argued that EU banks need substantial restructuring and downsizing to earn their cost of capital (see, among others, IMF, 2016a, 2017). Constancio (2017) has emphasized the need to lower high NPLs in some countries, and to reduce high operating costs in others, with the latter potentially reflecting excessive reliance on physical rather than digital channels of distribution as well as excess capacity. IMF (2017b) and IMF (2017c) shows that NPLs, cost efficiency and cyclical factors impact the profitability of Spanish and Dutch banks as well as that of their European peers. IMF (2016) studies large French banks and other GSIBs and shows that leverage, reliance on wholesale funding, cost efficiency, as well as cyclical factors affect resilience to shocks and profitability. Whatever the diagnosis, rebuilding sustainable levels of bank profitability has been seen as key to ensure a resilient banking system that can provide credit and financial services in support of the economy (IMF, 2017a). 
In the first part of this paper, we document the financial boom and bust cycle experienced by EU banks by examining key bank performance indicators from balance sheet and income statements for a sample of listed and non-listed EU banks over 2000-16. This period covers the full length of the financial cycle, which we divide in four phases: pre-boom, boom, crisis, and recovery. The length of this cycle matches the average financial cycle length of around 16 years that is documented for some advanced economies since the 1960s (Borio, 2014). To highlight changes across the different phases of the cycle, we abstract from short-term variation by averaging the key variables of interest over each phase. We also examine differences across groups of banks by country of origin and size. Finally, to obtain a more complete picture, we compare EU Global Systemically Important Banks (G-SIBs) with GSIBs headquartered in other regions.

In the second part of the paper, by means of a simple empirical model, we try to shed light on the bank-level factors driving the evolution of profitability over the different phases of the financial cycle, including several indicators of business models such as the share of wholesale funding in total funding, cost efficiency or the composition of income. ${ }^{2} \mathrm{We}$ also study which bank characteristics differentiate EU banks that were adequately profitable in the post-crisis period from other banks.

Our main findings can be summarized as follows. First, not surprisingly banks that managed to contain the rise in NPLs were better able to preserve their profitability. Second, cost discipline has been important, as reductions in operating costs translated in better profit performance. Third, banks that reduced their assets more aggressively during the crisis experienced a smaller decline in profits in the post-crisis years. Fourth, better profit performance post-crisis is associated with larger decline in the share of wholesale funding. Contrary to expectations, we also show that net interest margins (NIM) remained broadly stable over the financial cycle. Finally, we do not find evidence that variables capturing diversification of income sources, such as the reliance on fees and commission income, were associated with better profit performance in the post-crisis environment.

The paper is organized as follows. The next section explains the sample construction. Section III provides stylized facts on key indicators of bank performance. Section IV presents a decomposition of profitability. Section V introduces the empirical model. Section VI discusses the results. Section VII concludes.

\section{THE SAMPLE}

To construct the sample, we gather balance sheet and income statement data from the Fitch database for all EU banks that report statements at the consolidated level over the period 2000-2016. This selection excludes banks that report only unconsolidated accounts (usually smaller banks that do not have subsidiaries) and subsidiaries (to avoid double-

\footnotetext{
${ }^{2}$ Recent papers have developed methodologies to classify banks into different business models. See for instance Roengpitya, Tarashev, and Tsatsaronis (2014).
} 
counting with the parent bank). We choose bank statements at the highest level of consolidation because we believe that overall bank profitability is better assessed at the group level than at the subsidiary level. A similar approach is followed by the European Banking Authority (EBA) in its periodic transparency exercise and stress tests. For some banks, the highest level of consolidation is a holding company which includes sizable non-banking activities. In these cases, we use data for the legal entity where banking activities appear to be mainly concentrated. Our sample contains 114 EU banks (see Table A1 for a distribution of banks by country). ${ }^{3}$ To carry out international comparisons, we also compile data for the universe of the G-SIBs. ${ }^{4}$

To better understand heterogeneity within the sample, the descriptive analysis combines banks by country groups as well as by asset size quartiles. We distinguish four groups of countries: Eastern EU (Hungary, Poland, Romania, Slovenia), Nordics (Denmark, Finland, Sweden), Other EU (Austria, Belgium, France, Germany, Luxembourg, Netherlands, UK), and the group of countries that were severely affected by the euro crisis in 2010-12 (Cyprus, Greece, Ireland, Italy, Portugal, Spain). We refer to the latter group as the "euro crisis six" or "EC-6" in the rest of the paper. Whereas countries across all the regions experienced significant banking sector distress before and during the euro crisis, the sovereign-bank nexus made the crisis especially insidious in the EC-6.

It is important to note that many banks in our sample have sizable operations outside the country in which the main legal entity is located. In addition, some national banking markets are dominated by affiliates of foreign banks. Hence, using consolidated data means that some countries only have a handful of banks in the sample. Furthermore, for large international groups, performance may be strongly influenced by macroeconomic conditions outside the country to which the bank is attributed.

Another feature of the data is that indicators may change over time because of mergers and acquisitions. In fact, the high growth rates of assets before the crisis that we document likely indicate that the banks in the sample were actively growing through mergers and acquisitions. Some of the changes in funding or business orientation may also be the result of mergers or acquisitions. This is not a source of bias or other concerns, but it just needs to be kept in mind in interpreting the findings. Finally, the sample is affected by survivorship bias, as banks that closed during the sample period are excluded. However, most troubled banks in the EU were rescued rather than allowed to fail, so this bias is probably not too problematic. We acknowledge that we do not have a mean to address such potential biases.

\footnotetext{
${ }^{3}$ Our sample overlaps to a great extent with that of the EBA transparency exercise, which considered 105 banks in 2015, 131 banks in 2016, and 132 banks in 2017.

${ }^{4}$ See Appendix B for the list of G-SIBs considered. Total assets for U.S. banks are adjusted to reflect differences in accounting standards.
} 
We break up the sample period in four subperiods: 2000-04 (pre-boom), 2005-07 (boom), 2008-12 (crisis), and 2013-16 (post-crisis). We divide up the pre-crisis years in two subperiods because the years immediately before the global financial crisis may have been characterized by an abnormal expansion, so that comparison with a more normal period (2000-04) may provide additional insight.

\section{STylized FACTS: BoOM AND BUST IN THE EU BANKIng SECTOR}

To place EU bank performance in context, it is useful to start by documenting key developments over the financial cycle considering each subperiod separately. To this end, in this section, we investigate bank performance and resilience, assessing what has changed in recent years relative to earlier periods. We consider various indicators of bank profitability, asset quality, dividend policy, size, capitalization, and funding. To avoid biases arising from outliers, we exclude observations above and below the top and bottom one percent of the distribution, respectively, of each of the following variables: ROA, ROE, and assets growth. All statistics are weighted by bank size. The results (not reported) for tests of differences in means between the boom and post-crisis for all key bank indicators discussed are generally significant at the 1 percent level.

\section{Profitability}

Profitability displays a pronounced boom-bust pattern (Table 1). ROAs and (especially) ROEs rose during the boom years, declined dramatically during the crisis, and remained depressed thereafter. Figure 2 shows how pervasive the decline in profit has been: in almost all the banks in the sample, ROEs were lower post crisis than in the boom years, in many cases very sharply so. Hence, the averages shown in Table 1 are not just produced by a few "problem cases."

Nordic banks were the most profitable group post crisis, with an ROE of 9.1 percent, down from 13.8 percent in the pre-boom period. In contrast, the sharpest decline in ROE was registered in EC-6 banks, partly reflecting the need to provision for high NPLs (Table 2). Interestingly, a sharp decline in ROE is also evident in banks from Other EU even though NPLs were a much more limited problem. This may reflect falling income from investment banking activities in large, universal banks. Another noticeable finding is that net interest margins declined between the pre-boom years and the boom period, but remained on average broadly stable since then. This suggests that the main driver of the decline in ROA since the boom was not lower margins on traditional intermediation, but other components of profitability. We investigate this in more detail in the next section.

Turning to the G-SIBs, the EU experience has been somewhat different than that of other global banks. Chinese global banks remained very profitable post-crisis, and both Japanese

and U.S. banks managed to rebuild their profitability much better than EU and Swiss global banks, though not to the levels seen during the boom years. 


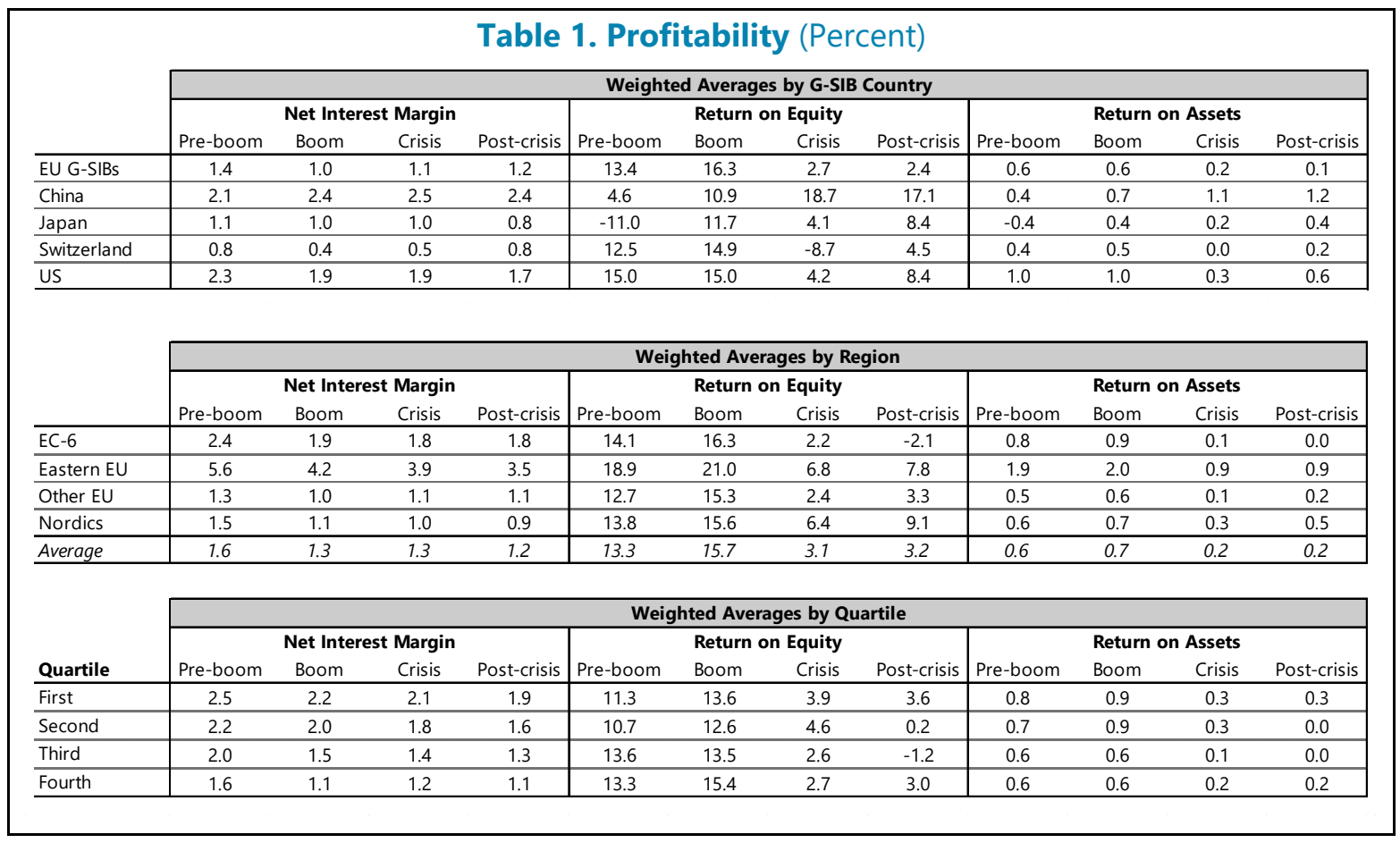

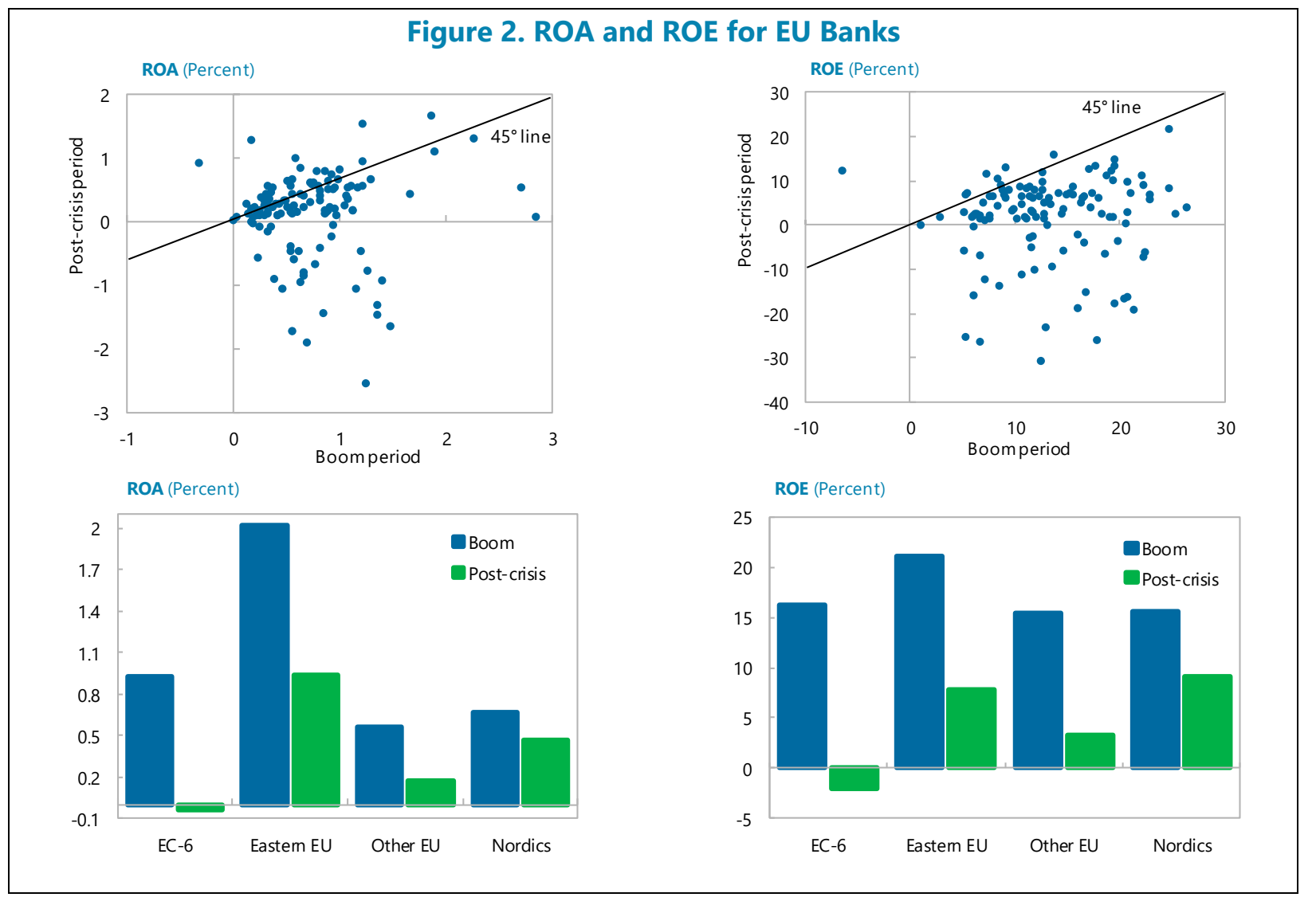

CInternational Monetary Fund. Not for Redistribution 


\begin{tabular}{|c|c|c|c|c|c|c|c|c|c|c|c|c|c|c|}
\hline \multicolumn{15}{|c|}{ Table 2. Asset Quality (Percent) } \\
\hline & \multirow{2}{*}{\multicolumn{4}{|c|}{ Weighted Averages by Region }} & \multirow[b]{3}{*}{ Quartile } & \multirow{2}{*}{\multicolumn{4}{|c|}{$\begin{array}{c}\text { Weighted Averages by Quartile } \\
\text { NPLs / Gross loans }\end{array}$}} & & \multicolumn{4}{|c|}{ Weighted Averages by G-SIB Country } \\
\hline & \multicolumn{2}{|c|}{\begin{tabular}{|c|} 
NPLs / Gross loans \\
\end{tabular}} & & & & & & & & & & NPLs / & ss loans & \\
\hline & Pre-boom & Boom & Crisis & Post-crisis & & Pre-boom & Boom & Crisis & Post-crisis & & Pre-boom & Boom & Crisis & Post-crisis \\
\hline$E C-6$ & 2.1 & 2.5 & 7.3 & 14.5 & First & 2.4 & 3.0 & 6.3 & 10.1 & EU G-SIBs & 2.4 & 2.2 & 3.9 & 4.6 \\
\hline Eastern EU & 7.2 & 4.1 & 10.4 & 13.9 & & & & & & China & 20.8 & 8.3 & 1.6 & 1.4 \\
\hline Other EU & 3.3 & 2.4 & 4.3 & 4.5 & Second & 2.8 & 2.8 & 4.8 & 14.4 & Japan & 7.2 & 2.4 & 2.2 & 1.7 \\
\hline Nordics & 1.0 & 0.6 & 2.1 & 2.1 & Third & 2.2 & 2.1 & 5.8 & 10.0 & Switzerland & 2.7 & 0.8 & 1.4 & 0.6 \\
\hline Average & 2.7 & 2.1 & 4.7 & 6.7 & Fourth & 2.6 & 2.4 & 4.7 & 5.1 & US & 1.2 & 0.4 & 2.9 & 1.9 \\
\hline
\end{tabular}

Faced with sharply declining profitability, banks in Eastern EU and the EC-6 protected their capital by cutting back dividend payouts in the post-crisis period (Table 3 ). In contrast, banks in Other EU and the Nordics appeared to have smoothed dividends, with the result that payout ratios to shareholders rose to close to 70 percent in the post-crisis years compared with around 50 percent pre-crisis. For the largest banks, post-crisis dividend payout ratios were very high from a historical perspective, averaging close to 75 percent of earnings. In contrast, distributed earnings declined considerably in U.S., where G-SIB dividend payout ratios dropped to 18 percent post crisis. Lower payout ratios, likely enforced by supervisors including in the context of stress testing, may have helped U.S. G-SIBs improve their capital more rapidly than their EU peers.

\begin{tabular}{|c|c|c|c|c|c|c|c|c|c|c|c|c|c|c|}
\hline \multicolumn{15}{|c|}{ Table 3. Dividend Policy (Percent) } \\
\hline & \multicolumn{4}{|c|}{ Weighted Averages by Region } & \multirow[b]{3}{*}{ Quartile } & \multirow{2}{*}{\multicolumn{4}{|c|}{ Weighted Averages by Quartile }} & & \multicolumn{4}{|c|}{ Weighted Averages by G-SIB Country } \\
\hline & & ividend & yout ra & & & & & & & & & ividend & out rat & \\
\hline & Pre-boom & Boom & Crisis & Post-crisis & & Pre-boom & Boom & Crisis & Post-crisis & & Pre-boom & Boom & Crisis & Post-crisis \\
\hline$\overline{\mathrm{EC}-6}$ & 42.9 & 34.1 & 98.9 & 17.4 & First & 48.0 & -72.3 & 32.2 & 34.4 & $\overline{E U ~ G-S I B S}$ & 60.3 & 20.7 & -22.5 & 50.6 \\
\hline Eastern EU & 20.6 & 37.0 & 48.7 & 29.6 & Second & 41.5 & 36.7 & 53.1 & 58.1 & China & 52.5 & 28.1 & 38.4 & 32.4 \\
\hline Other EU & 56.1 & 33.7 & 3.9 & $\frac{29.6}{70.6}$ & Third & 40.2 & 35.8 & 67.7 & 35.8 & Japan & 4.2 & 1.4 & 12.9 & 19.9 \\
\hline Nordics & 46.0 & 36.7 & 198.3 & 6.0 .4 & Fourth & 60.8 & 38.5 & 48.9 & 74.9 & Switzerland & 32.1 & -- & 8.5 & 19.0 \\
\hline Average & 50.9 & 34.3 & 57.9 & 57.3 & & & & & & US & 47.9 & 54.3 & 29.8 & 18.6 \\
\hline
\end{tabular}

\section{Asset growth}

The pre-crisis years saw a rapid expansion in EU bank activities, with assets growing on average at annual rates of over 15 percent in the pre-boom years and over 20 percent during the boom. Balance sheet expansion came to a halt during the crisis and turned into a contraction in the post-crisis period (Table 4). A similar boom-bust pattern is visible in bank lending. These trends by-and-large affected banks in all country and size groups, though some differences are visible. For instance, asset and loan growth was very strong in Nordic and Eastern European banks and in smaller banks already in the pre-boom years. For U.S. banks, the boom-bust cycle took place earlier than for European G-SIBs, with asset growth peaking in the pre-boom period. While our data do not allow us to separate domestic from foreign assets, it is well established that a sizable part of the rise and fall in EU bank assets consisted of cross-border assets. For instance, McCauley et al. (2017) documents this trend and claims that deleveraging by European banks displayed "home bias", i.e. it affected crossborder activities disproportionately while the home market was protected. 


\begin{tabular}{|c|c|c|c|c|c|c|c|c|c|}
\hline \multicolumn{10}{|c|}{ Table 4. Bank Assets: Yearly Rate of Growth (Percent) } \\
\hline & \multicolumn{9}{|c|}{ Weighted Averages by Region } \\
\hline & \multicolumn{4}{|c|}{ Assets } & \multicolumn{4}{|c|}{ Loans } & \multirow{2}{*}{$\begin{array}{c}\text { Asset Size } \\
\text { (Million USD) }\end{array}$} \\
\hline & Pre-boom & Boom & Crisis & Post-crisis & Pre-boom & Boom & Crisis & Post-crisis & \\
\hline$\overline{E C-6}$ & 13.8 & 21.4 & 1.6 & -6.2 & 15.5 & 25.6 & 0.8 & -8.2 & 151,797 \\
\hline Eastern EU & 29.3 & 28.7 & 5.4 & -0.6 & 40.9 & 40.5 & 7.6 & -4.8 & 10,482 \\
\hline Other EU & 16.1 & 23.0 & -0.6 & -7.3 & 15.1 & 21.2 & 1.3 & -5.0 & 401,086 \\
\hline Nordics & 21.7 & 20.8 & 4.1 & -4.7 & 23.9 & 19.8 & 1.9 & -3.9 & 116,349 \\
\hline \multirow[t]{3}{*}{ Average } & 16.7 & 22.4 & 0.8 & -7.2 & 17.1 & 22.4 & 1.4 & -5.9 & 289,365 \\
\hline & \multicolumn{9}{|c|}{ Weighted Averages by Quartile } \\
\hline & \multicolumn{4}{|c|}{ Assets } & \multicolumn{4}{|c|}{ Loans } & Asset Size \\
\hline Quartile & Pre-boom & Boom & Crisis & Post-crisis & Pre-boom & Boom & Crisis & Post-crisis & (Million USD) \\
\hline First & 17.6 & 18.7 & 3.2 & -2.7 & 24.5 & 21.1 & 2.8 & -3.6 & 7,992 \\
\hline Second & 19.2 & 20.8 & 3.2 & -5.0 & 22.4 & 21.2 & 4.2 & -3.1 & 17,243 \\
\hline Third & 16.8 & 19.4 & 1.3 & -6.9 & 18.6 & 22.8 & 7.2 & -7.5 & 56,094 \\
\hline \multirow[t]{4}{*}{ Fourth } & 15.4 & 24.0 & 0.3 & -7.2 & 14.4 & 21.7 & -0.1 & -5.5 & 436,377 \\
\hline & \multicolumn{9}{|c|}{ Weighted Averages by G-SIB Country } \\
\hline & \multicolumn{4}{|c|}{ Assets } & \multicolumn{4}{|c|}{ Loans } & Asset Size \\
\hline & Pre-boom & Boom & Crisis & Post-crisis & Pre-boom & Boom & Crisis & Post-crisis & (Million USD) \\
\hline EU G-SIBS & 14.6 & 24.1 & 1.2 & -7.9 & 11.0 & 21.1 & 2.7 & -4.8 & 491,362 \\
\hline China & 11.0 & 20.6 & 20.5 & 7.4 & 10.3 & 14.0 & 20.7 & 8.7 & 484,127 \\
\hline Japan & 16.1 & -3.6 & 12.2 & -1.6 & 8.2 & -4.2 & 8.7 & -3.0 & 548,095 \\
\hline Switzerland & 20.3 & 9.2 & -5.0 & -7.7 & 10.6 & 14.9 & -2.2 & 0.1 & 381,886 \\
\hline US & 22.0 & 14.6 & 12.6 & -3.3 & 50.0 & 10.2 & 7.7 & 11.3 & 574,118 \\
\hline
\end{tabular}

\section{Leverage}

Next, we examine whether rapid balance sheet expansion pre-crisis was accompanied by an increase in bank leverage. We measure capitalization (the inverse of leverage) by the ratio of tangible common equity to tangible assets (TE ratio) (Table 5). This ratio is not the concept of capitalization or leverage used in bank regulation. ${ }^{5}$ Regulatory measures of capital adequacy are difficult to compare across time in the period under consideration, as the definitions of both the numerator and the denominator changed because of regulatory reforms. In contrast, the TE ratio should be broadly comparable across time. In addition, at the numerator the TE ratio includes only high quality, loss-absorbing capital, and at the denominator assets are not risk-adjusted. This sidesteps concerns about differences in risk weights for similar exposures across banks and countries. In addition, internal model measures of risk may be sensitive to the financial cycle, generating low measured risk during booms and high measured risk during busts. For these reasons, movements in the TE ratio

\footnotetext{
${ }^{5}$ A similar picture emerges if considering the ratio of common equity to assets (not reported).
} 
may be a more meaningful measure of bank capital buffers over the financial cycle than regulatory capital. ${ }^{6}$

Large banks had considerably lower TE ratio than small banks in the pre-boom crisis (3.4 percent versus 6.0 percent). Capitalization fell to its lowest level during the boom (2.8 percent), likely because the use of internal risk models allowed banks to expand their balance sheet without a proportionate increase in capital. Supporting this view, smaller banks, which continued to use standardized risk models, experienced only a slight decline in the TE ratio during the boom. From a regional perspective, banks in Eastern EU were the best capitalized pre-crisis (TE ratio above 8 percent), while those in Other EU had substantially lower capital ratios, hovering around 3 percent. TE ratios in EU G-SIBs compared favorably to those of non-EU, non-U.S. G-SIBs in the pre-boom years, but they fell below those of peers in the period immediately preceding the crisis. This reversal may reflect the more

\begin{tabular}{|c|c|c|c|c|}
\hline \multicolumn{5}{|c|}{ Table 5. Capitalization (Percent) } \\
\hline & \multicolumn{4}{|c|}{ Weighted Averages by Region } \\
\hline & \multicolumn{4}{|c|}{ Tangible common equity/Tangible assets } \\
\hline & Pre-boom & Boom & Crisis & Post-crisis \\
\hline EC-6 & 4.5 & 4.4 & 4.2 & 5.2 \\
\hline Eastern EU & 9.5 & 8.0 & 9.1 & 10.5 \\
\hline Other EU & 3.2 & 2.8 & 2.9 & 4.4 \\
\hline Nordics & 4.2 & 3.8 & 3.6 & 4.6 \\
\hline Average & 3.8 & 3.4 & 3.4 & 4.6 \\
\hline \multirow[b]{3}{*}{ Quartile } & \multicolumn{4}{|c|}{ Weighted Averages by Quartile } \\
\hline & \multicolumn{4}{|c|}{ Tangible common equity/Tangible assets } \\
\hline & Pre-boom & Boom & Crisis & Post-crisis \\
\hline First & 6.0 & 5.8 & 5.9 & 7.2 \\
\hline Second & 6.1 & 6.3 & 5.5 & 6.7 \\
\hline Third & 4.4 & 3.8 & 3.8 & 4.7 \\
\hline \multirow[t]{4}{*}{ Fourth } & 3.4 & 2.8 & 2.9 & 4.3 \\
\hline & \multicolumn{4}{|c|}{ Weighted Averages by G-SIB Country } \\
\hline & \multicolumn{4}{|c|}{ Tangible common equity/Tangible assets } \\
\hline & Pre-boom & Boom & Crisis & Post-crisis \\
\hline EU G-SIBs & 3.1 & 2.5 & 2.7 & 4.1 \\
\hline China & 2.3 & 3.7 & 5.7 & 6.8 \\
\hline Japan & 2.0 & 3.4 & 2.9 & 4.7 \\
\hline Switzerland & 2.0 & 1.9 & 2.0 & 3.9 \\
\hline US & 4.7 & 4.1 & 3.9 & 5.6 \\
\hline
\end{tabular}
widespread adoption of internal risk models in the EU.

After the crisis, EU banks became better capitalized - likely a reaction to regulatory and market pressures. In the Nordic banks, which fared relatively well doing the crisis, and in banks in the EC-6, which were severely affected, the increase in the TE ratio relative to the pre-boom years was smaller than in Eastern EU and Other EU banks. All in all, after the crisis banks in Other EU and in the Nordic region remained more leveraged than banks in the rest of the EU. In terms of size, the largest banks were more leveraged than smaller banks throughout the financial cycle. Within the G-SIBs, capital levels in banks from the EU (and Switzerland) remained below those of other G-SIBs despite having increased in recent years.

\footnotetext{
${ }^{6}$ Demirgüç-Kunt, Detragiache, and Merrouche (2013) shows that banks with lower initial TE ratios experienced more severe decline in stock prices during the financial crisis, while differences in regulatory capital ratios do not have explanatory power.
} 


\section{Funding}

The large balance sheet expansion of the pre-crisis years was funded to a significant extent through higher reliance on the wholesale market (Table 6). ${ }^{7}$ This was the case in all country groups and for banks of all sizes, but less so for small banks. The most marked increase was in Other EU banks and in Eastern EU banks. In the latter, hardly any wholesale funding existed in the pre-boom years. Following the severe market disruptions during the crisis, reliance on wholesale funding declined in all regions except in the Nordic region, where banks continued to expand their use of covered bonds to fund mortgages.

Customer deposits correspondingly increased in all but the Nordic banks, and the loan-to-deposit ratio (not shown) declined, particularly in the EC-6. The rise and fall of wholesale funding was particularly pronounced for the largest banks and for the EU G-SIBs.

To summarize, rapid balance sheet

\begin{tabular}{|c|c|c|c|c|}
\hline \multicolumn{5}{|c|}{ Table 6. Wholesale Funding (Percent) } \\
\hline & \multicolumn{4}{|c|}{ Weighted Averages by Region } \\
\hline & \multicolumn{4}{|c|}{ Wholesale funding / Total funding } \\
\hline & Pre-boom & Boom & Crisis & Post-crisis \\
\hline EC-6 & 30.3 & 38.7 & 32.9 & 26.3 \\
\hline Eastern EU & 3.1 & 12.4 & 12.0 & 6.4 \\
\hline Other EU & 23.1 & 39.2 & 33.7 & 27.4 \\
\hline Nordics & 39.2 & 44.1 & 48.9 & 49.0 \\
\hline Average & 25.9 & 37.8 & 34.3 & 29.3 \\
\hline \multirow[b]{3}{*}{ Quartile } & \multicolumn{4}{|c|}{ Weighted Averages by Quartile } \\
\hline & \multicolumn{4}{|c|}{ Wholesale funding / Total funding } \\
\hline & Pre-boom & Boom & Crisis & Post-crisis \\
\hline First & 30.2 & 26.0 & 24.8 & 17.8 \\
\hline Second & 26.9 & 33.8 & 33.2 & 25.5 \\
\hline Third & 30.8 & 40.3 & 38.0 & 33.9 \\
\hline \multirow[t]{4}{*}{ Fourth } & 25.7 & 40.5 & 34.1 & 27.8 \\
\hline & \multicolumn{4}{|c|}{ Weighted Averages by G-SIB Country } \\
\hline & \multicolumn{4}{|c|}{ Wholesale funding / Total funding } \\
\hline & Pre-boom & Boom & Crisis & Post-crisis \\
\hline EU G-SIBs & 25.9 & 38.8 & 32.7 & 27.9 \\
\hline China & 3.8 & 3.8 & 2.9 & 5.1 \\
\hline Japan & 26.9 & 24.9 & 21.6 & 21.2 \\
\hline Switzerland & 22.9 & 31.1 & 35.1 & 29.3 \\
\hline US & 53.4 & 50.8 & 35.1 & 27.6 \\
\hline
\end{tabular}
expansion accompanied by increased leverage and reliance on wholesale funding during the boom allowed EU banks to earn large returns on equity. Once the boom turned to bust, however, profits rapidly dwindled as banks had to downsize, deleverage, and rein in wholesale funding, while asset quality sharply deteriorated.

\section{DEComposing The DeCline in BANK Profitability}

To better understand the decline in EU bank profitability over the financial cycle, we break down changes in return on assets (ROA) into its various components. As documented in the previous section, the decline in leverage compounded the effect of lower ROA on ROE. Using accounting identities, the basic decomposition is as follows:

\section{$\Delta R O A=\Delta N I M+\Delta N o n$-interest income $-\Delta$ Non-interest expense - $\Delta$ Loan Loss Provisions $+\Delta$ Net other income,}

\footnotetext{
7 The wholesale funding ratio is defined as (total funding - deposits - equity)/(total funding-equity). It includes central bank liquidity provision.
} 
where

$$
\begin{aligned}
& \quad \Delta \text { NIM }=\Delta \text { Interest income }-\Delta \text { Interest expense, } \\
& \Delta \text { Non-interest income } \\
& =\Delta \text { Trading income }+\Delta F e e s \& \text { commissions incl.insurance income } \\
& +\Delta \text { Other operating income. }
\end{aligned}
$$

Net other income includes non-customer loan impairment charges, net recurring income not related to the core business, extraordinary net income, tax expenses, and profit/loss from discontinued operations.

Figure 3 graphs the results from the above decomposition of ROA, with bank data first grouped at the country level using average assets as weights and then at the country-group level using average assets by country as weights. The chart shows that the decline in ROA was most pronounced in Eastern EU, followed by the EC-6, Other EU, and the Nordics. Furthermore, the evolution of the various components of profitability is quite different across country groups. ${ }^{8}$ In Eastern EU, the large decline in bank profitability was the result of a sharp fall in both NIM and non-interest income, as well as of an increase in loan-loss provisions, only partially offset by the sizable contraction in operating expenses. In contrast, in the EC-6 the decline in profitability was mainly driven by the need to provision for NPLs, which was not offset by operational cost savings. In Other EU, in turn, the decline in ROA mainly reflected a fall in revenue from non-traditional banking activities. ${ }^{9}$ Finally, in the Nordic banks a reduction in income from non-traditional activities and some increased provisioning contributed to lower ROA, but operational cost savings contained the extent of the deterioration.

\footnotetext{
${ }^{8}$ Tests of differences in means for all variables considered confirm that these changes between the boom and post-crisis are statistically significant (results not reported).

${ }^{9}$ Further disaggregating this profit component, there appears to be no systematic decline in trading income, fees and commissions (including insurance income), and the decline seem to originate mostly in the "other noninterest income" category. This is defined by Fitch as other sustainable income, which is related to the entity's core business and does not fall into any other category.
} 


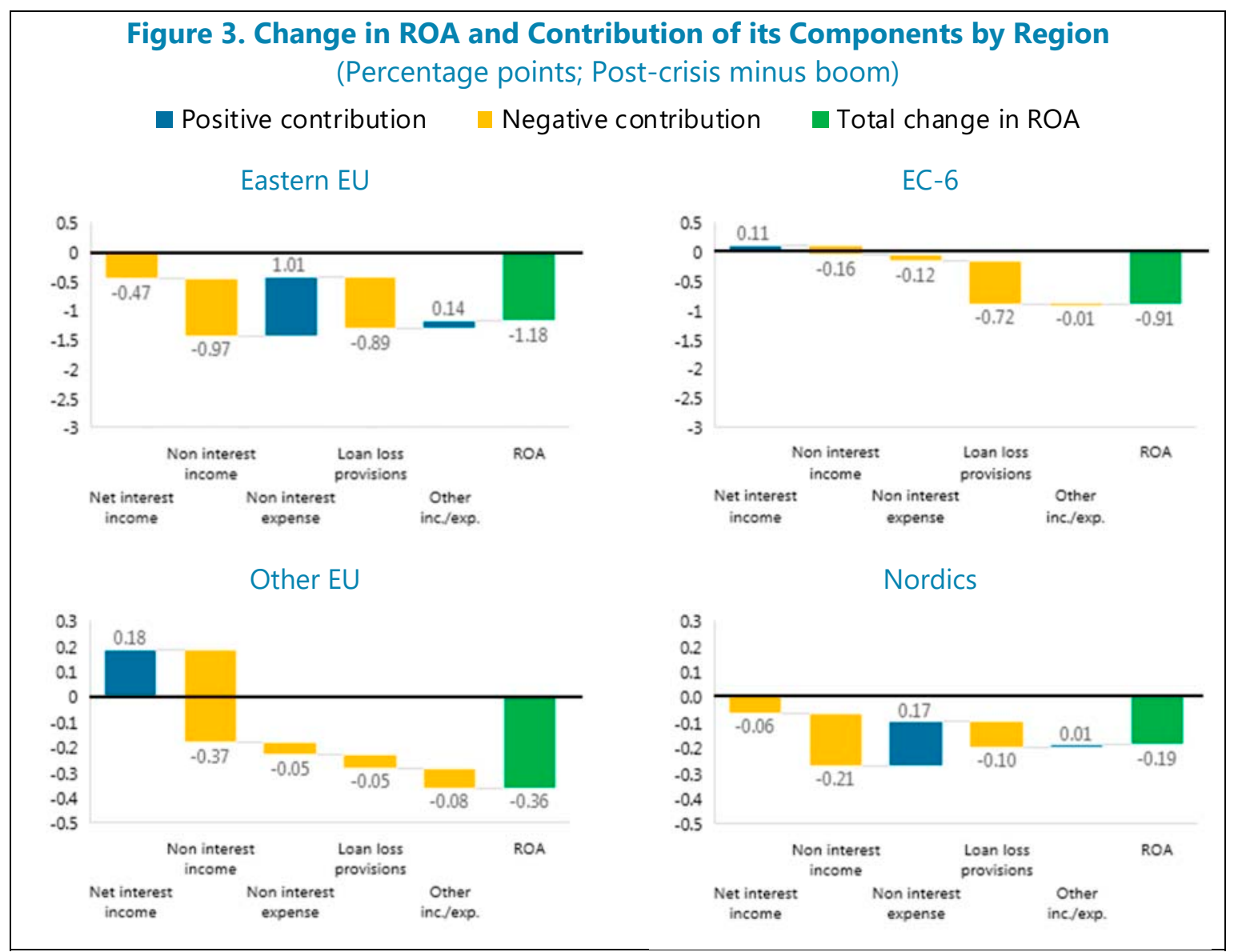

Interestingly, despite the current intense debate over the impact of low interest rates on intermediation margins, the only region where the decline in the NIM was sizable is Eastern EU, while in Other EU the NIM improved. ${ }^{10}$ This suggests that, at least during the period under consideration, banks were largely able to offset lower lending rates with lower funding costs. ${ }^{11}$ A closer look at the NIM components (not reported) reveals that indeed both interest income and interest costs decreased in all countries (except the Netherlands), thus cushioning the effect of lower interest income in the low interest rate environment. However, when we divide banks based on asset size (Figure 4), it becomes evident that small banks were affected by worsening intermediation spreads, while the largest banks in the sample

\footnotetext{
${ }^{10}$ A growing body of empirical literature finds that banks' net interest margin (NIM) is being squeezed from historically low interest rates as well as from flatter yield curves (Claessens, Coleman, and Donnelly, 2016; Busch and Memmel, 2015), although the effects may be non-linear as rate cuts may have larger effects if starting from already low levels (Borio, Gambacorta, and Hofman, 2015). But Genay and Podjasek (2014) argue that the negative effects on bank profitability are economically small and outweighed by greater lending volume from low interest rates that boost economic activity. Ennis, Fessenden, and Walter (2016) further find that the relationship between interest rates and NIMs is not clear-cut.

${ }^{11}$ A similar finding is reported for Denmark and Sweden - two countries in which interest rates were low and negative for an extended period - where bank margins remained broadly stable (Turk, 2016).
} 
registered a slight increase in NIM. Not surprisingly, the decline in non-interest income mattered more for large banks than small banks, as the former banks rely more heavily on non-traditional activities.

Turning to G-SIBs (Figure 5), intermediation spreads rose for EU banks, but declined for other banks. All G-SIBs except the Swiss and Chinese saw a decline in earnings from nontraditional sources. The bottom line for EU G-SIBs was affected by greater increases in operating and provisioning costs relative to other G-SIBs. In contrast, U.S. G-SIBs compensated their loss of income by sharp cost cutting.

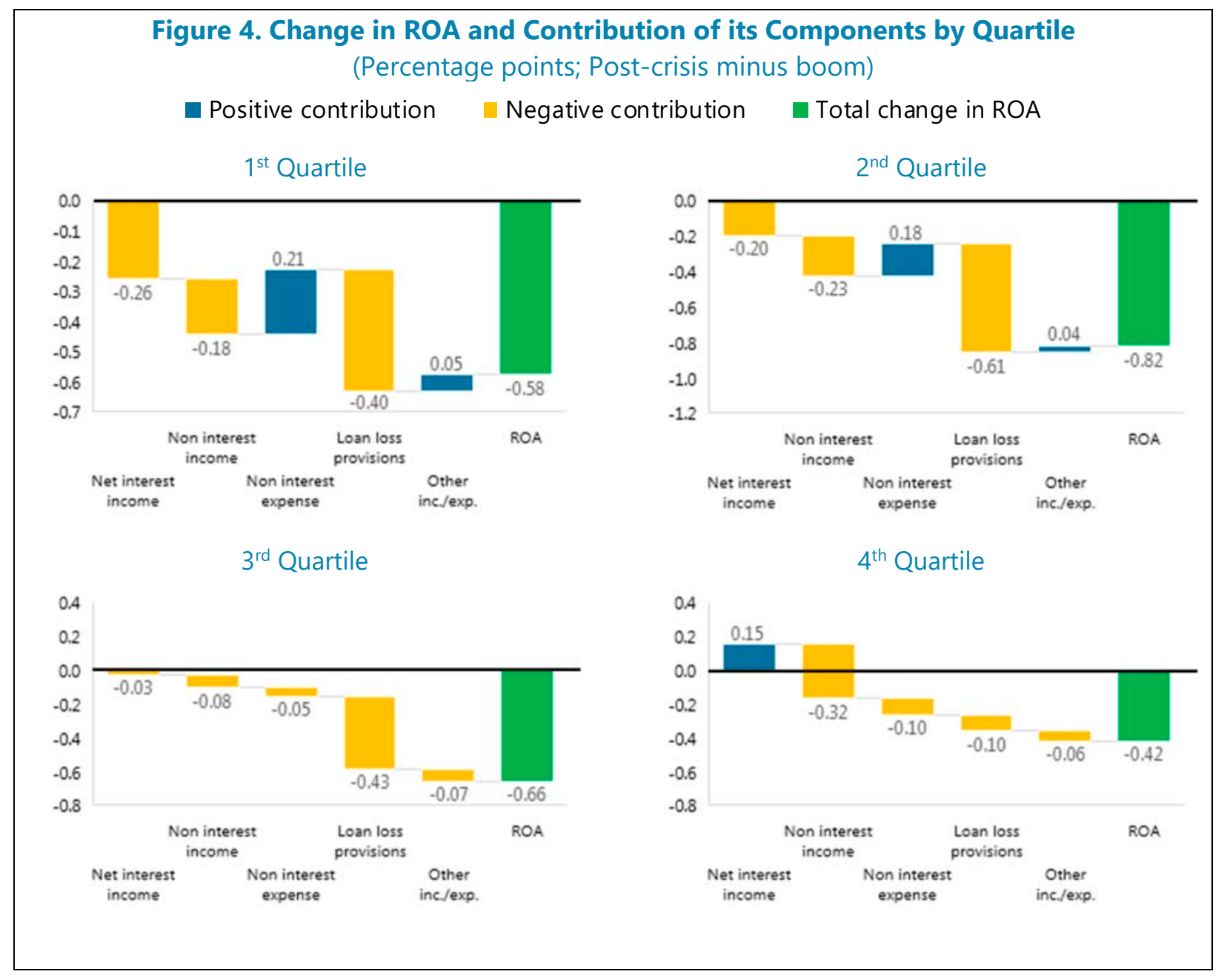




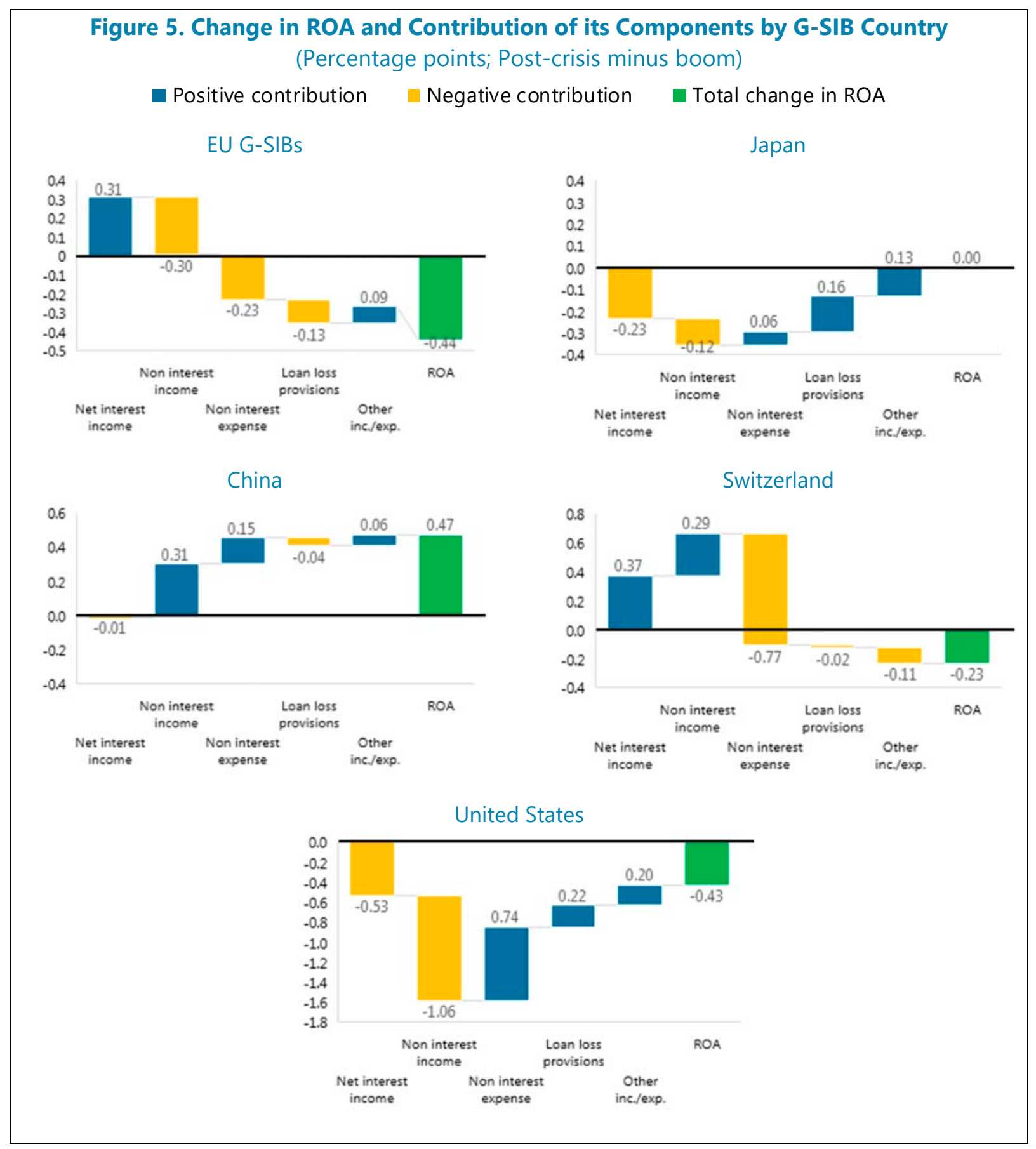

\section{Explaining Changes in Bank Profitability OVer the Financial CyCle}

\section{Empirical specifications}

In this section, we use multivariate analysis to further understand the factors associated with changes in the profitability of EU banks over the financial cycle, thus shedding light on bank characteristics or strategies adopted since the global financial crisis that may have helped shore up profits. 
We focus on profitability measured by ROA, which is less sensitive to changes in leverage than ROE. To smooth out the impact of temporary factors on profits, and in line with the presentation of the stylized facts in the previous section, we average the data in each subperiod of the financial cycle. We then consider changes in ROA between each phase of the financial cycle: pre-boom period (2000-2004) to boom period (2005-2007), boom period to crisis period (2008-2012), and crisis period to post-crisis period (2013-2016).

We hypothesize that changes in bank profitability through the financial cycle are associated with both bank-specific factors and macroeconomic conditions. Among bank-specific factors, we distinguish between "initial conditions," i.e. bank characteristics measured during the previous phase of the cycle, and contemporaneous changes in bank behaviors or conditions affecting profitability. Initial conditions are pre-determined variables, so they are relatively exempt from endogeneity concerns. However, we acknowledge that our findings related to contemporaneous changes in bank characteristics are only associations as reverse causality bias cannot be allayed. Therefore, we do not interpret these regression results as establishing causality, but only as highlighting conditional correlations.

Specifically, we estimate the following panel regression:

$$
\Delta Y_{i j t}=\alpha+\beta X_{i j t-1}+\gamma \Delta Z_{i j t}+\delta \Delta M_{j t}+\varepsilon_{i j t}
$$

where subscripts $i, j$, and $t$ denote banks, countries, and periods defined above, respectively. $\Delta Y_{i j t}$ refers to the change in profitability between periods. $X_{i j t-1}$ is a vector of bank initial characteristics averaged over the previous period; $\Delta Z_{i j t}$ is a vector of changes in bank variables from $t-1$ to $t$ (in percentage points); some specifications also include $\Delta M_{i t}$ which is a vector of changes in country-specific macroeconomic variables from $t-1$ to $t$ (in decimals); $\alpha, \beta, \gamma, \delta$ are vectors of coefficients to be estimated, and $\varepsilon_{i j t}$ is the error term.

The regressions are estimated using the same sample of banks used in the stylized facts section. The estimation is carried out using OLS with robust standard errors clustered at the bank level. ${ }^{12}$ With four stages in the financial cycle, changes in variables are calculated for three periods, so the panel has three periods. Period fixed effects control for common shocks, such as macroeconomic developments, regulatory changes, or structural breaks such changes in long-term trends in bank profitability. Some specifications also include regional fixed effects, with regions as defined in the previous sections (Eastern EU, EC-6, Nordics, and Other EU). ${ }^{13}$

Finally, since the impact of various factors on profitability may change over the financial cycle, we also run separate cross-sectional regressions for each of the three phases of the cycle.

\footnotetext{
12 In a robustness check, we winsorize variables with extreme observations (change in the ratio of wholesale funding to total funding, in asset growth, and in the ratio of tangible common equity to tangible assets) at the 5 percent of their distribution. The results are robust to such winsorization.

${ }^{13}$ Since for some countries we only have one or two banks we do not estimate specifications with country fixed effects, though in several specifications we use country-specific macroeconomic controls.
} 


\section{Explanatory variables - bank level variables}

Among bank-level initial conditions we include bank size (measured by the log of assets). Large banks, which often operate in different lines of business and different regions and have more sophisticated risk management than small banks, may be in a better position to adjust the scope and nature of their operations to changes in financial and regulatory conditions over the financial cycle. On the other hand, large banks may have more opportunities to take up excessive risk during the boom phase, and are often involved in more complex or risky lines of business. In the post-crisis phase, large banks, because of their systemic nature, may have had to adjust to more stringent regulatory changes than small banks.

The second initial conditions we include is the rate of past expansion (measured by the growth rate of assets over the previous subperiod). More aggressive expansion during the boom may have translated in larger profit gains initially, but these gains may have reversed after the boom gave way to the crisis. Alternatively, faster expansion may indicate better business strategies and could be followed by larger increase in profitability.

We also test whether a bank's funding model (measured by the share of wholesale funding in total funding) significantly affects profitability growth over the cycle. Banks capable of tapping wholesale funding may have been in a better position to finance rapid expansion or take advantage of new profit and risk-taking opportunities during the boom, possibly resulting in a more rapid decline in profits during the bust. Also, as wholesale markets froze during the crisis, banks more dependent on this type of funding may have been forced into costly fire sales of assets during the bust, negatively affecting profitability.

Next, the initial quality of the loan portfolio (measured by the ratio of NPLs to net loans) may also be related to future changes in profitability, as low past loan quality may be a sign of poor bank risk management and hence lower prospects for better performance in subsequent periods.

The initial share of interest income in total income aims to proxy for a business model that is more reliant on traditional banking activities; thus, the coefficient of this variable may inform on how this aspect of a bank business model affects changes in profitability over the financial cycle. Particularly, as discussed in the previous section, there has been an intense debate on whether the low interest rate environment created by central banks post crisis may be detrimental to banks that are more reliant on interest margins as a main source of earnings.

Finally, initial bank leverage, measured by the ratio of tangible equity over total assets, is also included in the set of potentially relevant initial conditions to inform whether banks with stronger buffers of high quality capital were in a better position to withstand unexpected losses, thereby avoiding costly de-leveraging during the crisis, and were better able to adapt to the new and more capital requirements of Basel III demanding higher and better loss absorbing capital. In all specifications, we control for initial bank profitability to control for mean reversion effects: if profits tend to revert to their long-term mean, banks experiencing higher than normal profits in period $t$ will be more likely to see their profits decline in $t+1$. In 
a competitive market, we would expect abnormal profits not to persist and thus the data to exhibit mean-reversion.

Turning to variables capturing contemporaneous changes in bank characteristics, we examine whether banks that changed their funding model were better able to protect profitability. For instance, switching out of wholesale funding into retail funding by taking advantage of an existing retail network (therefore without incurring large additional operating costs) may have helped profitability in the bust and post-crisis phases, when wholesale funding became less attractive for market reasons (during the crisis) and regulatory reasons (after the crisis). On the other hand, the low cost of wholesale funding in the post-crisis period might have helped banks protect their intermediation margins in the low interest environment, given possible downward rigidities in retail deposit rates (e.g., those arising from competitive pressures or potential regulatory constraints on saving accounts).

We also look at whether business model adjustments in terms of operating cost efficiencymeasured as the change in operating costs - translated into higher profits. This may not necessarily be the case if cost reductions reflect exit from profitable lines of business or markets by banks that were under pressure to deleverage rapidly. Another dimension of the business model is a bank's ability to diversify income sources, so we examine whether banks that increased their reliance on fees and commission income did better in terms of profitability in our sample. Finally, as shown in the previous section, a deterioration in loan quality was a major factor in bringing down profitability in several EU countries during and after the crisis, so the change in the NPL ratio is included as an additional regressor.

\section{Explanatory variables - macroeconomic variables}

In the basic specifications, we use period dummy variables and/or country-group dummy variables to control for unobserved factors common to all banks in each period and/or to banks in each country-group. However, since macroeconomic circumstances varied across countries within each group, it may be important to control for country-specific macroeconomic variables to more accurately assess the role played by bank-specific factors. However, as discussed in Section II, it must be acknowledged that, since several EU bank groups have operations and exposures outside their country of incorporation, the macroeconomic conditions that could affect their loan quality may well be beyond those of their domestic incorporation.

We experiment with various proxies of overall macroeconomic conditions (real GDP growth, the output gap, the unemployment rate), monetary conditions (proxies for policy interest rates, the term premium, aggregate credit growth), asset prices (stock price growth, housing price growth), and stress in the sovereign debt market (spreads relative to bunds). The difference between the average system-wide deposit interest rates and the policy rate may also be a useful control variable to capture some aspects of regulations (e.g., floors on banks' savings account rates, such as in France) as well as the degree of competition in the deposit market which may create downward rigidities in deposit rates. Some of these variables are highly correlated with each other, which makes it difficult to sort out which macroeconomic development is really captured by the variable in question. However, our analysis is focused on the role of bank characteristics, not on macroeconomic factors. 


\section{Sample summary statistics}

Summary statistics of all variables entering in the various versions of equation (1) are provided in Tables A3 and A4in the Appendix. The overall sample mean (respectively median) of profitability (ROA) is 0.24 percent (resp. 0.31 percent). Bank assets were on average growing at about 7.7 percent, likely driven by a few banks as the median growth was only 1.7 percent, but with a wide dispersion among banks and periods as indicated by the very high standard deviation. Wholesale funding was on average about 30 percent of total funding, but again with a very large dispersion, as some banks in the sample have virtually no wholesale funding, whereas other banks are almost entirely funded on the market. Nonperforming loans are on average 6.4 percent of gross loans, with a median at 3.9 percent, but we have a notable right tail of banks with high NPLs. Interest income accounts for 80 percent of total income on average, and tangible common equity is on average about 5 percent of total tangible assets.

Turning to changes in bank characteristics from one period to the next, ROA declined by 0.21 percentage points on average from one period to the next, with a median decline of 0.06 percentage points, driven by a tail of banks with large declines in ROA. The share of fees and commission income was approximately stable on average, but the average hides significant heterogeneity across banks. The share of wholesale funding was broadly stable over time, with an average (respectively median) decline of 1.72 percentage points (respectively 0.87 percentage points), but the dispersion of the change in this share was large across banks. Many banks embarked in cost cutting, as shown by the decline in the ratio of non-interest expenses to total assets. The ratio of non-performing loans to gross loans increased on average by 3 percentage points.

Table A4 shows pairwise correlations among bank variables. While statistically significant, the correlation between ROA and ROE is low, suggesting that bank leverage was changing substantially over the sample. ROA is positively correlated with asset growth and capitalization (as measured by the ratio of tangible common equity to tangible asset), with the change in ROA relative to the previous period and negatively with the level of NPLs and its change relative to the previous period. The change in profitability appears positively correlated with the change in operating expenses.

\section{EMPIRICAL FINDINGS}

\section{Panel regressions}

Table 8 presents the results of various specifications of the panel regression.

Beginning with bank-level variables, initial profitability enters negatively in the regression, i.e. banks are more likely to experience a decline in profits if they had higher profits in the past. Thus, profits tend to revert to an average or normal level. The size of the effect is substantial: a 100-basis points higher initial ROA is associated with a decline in profits of some 80 additional basis points in the subsequent phase of the financial cycle. This strong mean reversion suggests that cross-sectional differences in bank profits likely reflect to an 
important extent temporary factors and not systematic and persistent differences in profitability. But mean-reversion could also be associated to the financial cycle. Mean reversion is also consistent with a well-functioning competitive market, in which individual viable banks do not persistently overperform or underperform their competitors. Note that this mean reversion effect is significant even though we control for period dummies that capture the effect on profitability of common shocks - such as the effect of the crisis, macroeconomic factors or structural breaks.

Turning to factors that are systematically associated to changes in profitability, asset growth is negatively associated with the subsequent change in ROA, thus more rapid balance sheet expansions/contractions tend to be followed by declines/increases in profits. ${ }^{14}$ In terms of magnitude, a ten percentage-point higher asset growth in the previous phase of the cycle is associated with a subsequent decline in profitability of an additional 12 basis points (the unweighted average decline in ROA in the sample is of 21 basis points). We return to this relationship in the cross-sectional regressions.

Better capitalization, measured by the tangible equity ratio, is associated with better subsequent profit performance, possibly indicating that better capitalized banks managed to avoid costly deleveraging once the crisis hit. The magnitude of the effect, however, is not large: an increase in the tangible capital ratio of 1 percentage point (which would be quite sizable, considering the median TE ratio of 4.6 in the sample, see Appendix D) would raise ROA by slightly over 4 basis points. Furthermore, the coefficient is significant only at the 10 percent level.

Dummy variable indicators for the crisis period and the post-crisis period are very significant economically and statistically, suggesting that important common time effects affected the evolution of profitability in our sample. Even after controlling for bank-specific variables and regional fixed effects, common factors were associated with a decline in ROA of some 50 basis points during the crisis and a further 50 basis points in the post crisis period. Of the country-group dummies in column (3), that of "Other EU" is negative and significant, indicating that these banks had significant lower change in profits estimated at 18 basis points than Nordic banks (the omitted dummy is that for the Nordics) over the full cycle even after controlling for bank level variables. Other country-group effects are not significant.

\footnotetext{
14 This finding could indicate a potential trade-off between enhancing profitability at a microeconomic level by cutting assets and macroprudential concerns that arise when a credit crunch materialize during a financial crisis.
} 


\begin{tabular}{|c|c|c|c|c|c|c|c|}
\hline \multicolumn{8}{|c|}{ Table 8. Determinants of Changes in Profitability: Panel Regressions } \\
\hline & (1) & (2) & (3) & (4) & (5) & (6) & (7) \\
\hline \multicolumn{8}{|c|}{ Initial conditions (previous period) } \\
\hline ROA & $-0.839 * \star \star$ & $-0.852^{\star \star \star}$ & $-0.862^{\star \star \star}$ & $-0.851^{\star \star \star}$ & $-0.767^{\star \star \star}$ & $-0.807^{\star \star \star}$ & $-0.839 * \star \star$ \\
\hline Log(assets) & 0.0342 & 0.0240 & 0.0377 & 0.0344 & $2.65 e-05$ & 0.00876 & 0.0108 \\
\hline Asset growth & $-0.00429^{\star \star}$ & $-0.0126^{\star \star \star}$ & $-0.0122^{\star \star \star}$ & 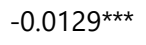 & $-0.0127^{\star \star \star}$ & $-0.0131^{\star \star \star}$ & $-0.0105^{\star * *}$ \\
\hline Wholesale / total funding & 0.00262 & -0.00264 & -0.00269 & -0.00215 & -0.00204 & -0.00155 & $8.63 e-05$ \\
\hline NPL / GL & $-0.0627^{\star \star}$ & -0.0285 & -0.0312 & -0.0191 & -0.0205 & -0.0226 & -0.0279 \\
\hline Share of interest income & $-0.241^{*}$ & 0.0687 & 0.0979 & 0.0492 & 0.00734 & 0.0157 & $-0.262^{\star \star}$ \\
\hline $\mathrm{TCE} / \mathrm{TA}$ & $0.0618^{\star \star}$ & $0.0440^{*}$ & 0.0409 & $0.0441^{*}$ & $0.0425^{\star}$ & $0.0448^{*}$ & $0.0519 * *$ \\
\hline \multicolumn{8}{|l|}{ Variables in changes } \\
\hline Share of fee \& com. Income & & 0.916 & 0.947 & 0.714 & 0.353 & 0.386 & -0.689 \\
\hline Wholesale / total funding & & $-0.0132^{\star \star *}$ & $-0.0136^{\star \star \star}$ & $-0.0124^{\star * *}$ & $-0.0129 * \star \star$ & $-0.0123^{\star \star \star}$ & $-0.0108^{* * *}$ \\
\hline Non interest Expenses / TA & & $-0.422^{\star \star \star}$ & $-0.419 * \star \star$ & $-0.441^{\star \star \star}$ & $-0.384^{\star \star \star}$ & $-0.407^{\star \star \star}$ & $-0.288^{\star}$ \\
\hline NPL / GL & & $-0.0617^{\star \star \star}$ & $-0.0638^{\star \star \star}$ & $-0.0682^{\star \star \star}$ & $-0.0607^{\star \star \star}$ & $-0.0564^{\star \star \star}$ & $-0.0581^{\star \star *}$ \\
\hline \multicolumn{8}{|l|}{ Period dummies } \\
\hline Crisis & $-0.810^{* * *}$ & $-0.520 * * \star$ & $-0.517^{\star \star \star}$ & -0.183 & & & \\
\hline Post-crisis & $-0.523^{\star \star \star}$ & $-0.563^{\star \star \star}$ & $-0.556^{\star \star \star}$ & $-0.282^{\star \star \star}$ & & & \\
\hline \multicolumn{8}{|l|}{ Regional dummies } \\
\hline EC-6 & & & -0.111 & $0.163^{*}$ & & & \\
\hline Eastern EU & & & 0.0796 & $0.822^{* * *}$ & & & \\
\hline Other EU & & & $-0.175^{\star \star}$ & -0.167 & & & \\
\hline \multicolumn{8}{|c|}{ Regional and period dummies interactions } \\
\hline EC -6 * crisis & & & & $-0.584^{\star \star \star}$ & & & \\
\hline Eastern EU * crisis & & & & $-0.781^{\star \star \star}$ & & & \\
\hline Other EU * crisis & & & & 0.00937 & & & \\
\hline EC- 6 * post crisis & & & & -0.254 & & & \\
\hline Eastern EU * post crisis & & & & $-1.307^{\star *}$ & & & \\
\hline Other EU * post crisis & & & & -0.124 & & & \\
\hline \multicolumn{8}{|l|}{ Macro-variables (change) } \\
\hline Dep rate - ST rate & & & & & $-0.237^{\star}$ & $-0.374^{\star \star \star}$ & -0.191 \\
\hline Stock price growth & & & & & $1.544^{\star \star \star}$ & & \\
\hline Real GDP growth & & & & & 0.0273 & $0.0576^{\star}$ & \\
\hline Spread to Bunds & & & & & & & $-0.109 * \star \star$ \\
\hline Constant & 0.384 & 0.480 & 0.439 & 0.258 & 0.260 & 0.471 & 0.569 \\
\hline Observations & 284 & 281 & 281 & 281 & 270 & 270 & 255 \\
\hline R-squared & 0.633 & 0.739 & 0.742 & 0.758 & 0.773 & 0.765 & 0.786 \\
\hline
\end{tabular}

To examine whether regional factors played different roles in different phases of the financial cycle, in the regression in column (4) we add interaction terms between the regional dummies and period dummies. Interestingly, while banks in the EC-6 and especially in Eastern EU had higher profits growth than Nordic banks during the boom (even after 
controlling for bank-level characteristics), this reversed during the crisis. ${ }^{15}$ Profit growth was particularly depressed in the EC-6, undoubtedly reflecting the serious financial crises in these countries, which experienced sovereign and/or private sector crisis intensified by the sovereign-bank nexus. Also, while the crisis dummy loses significance once interaction effects are introduced, the post-crisis dummy remains significantly negative, suggesting that factors common to all regions continued to depress the evolution of bank profitability in the most recent years. These common factors may include increased regulation, low policy interest rates and flat yield curves, as well as technological change. Finally, including or excluding regional dummies in the regression has minor effects on the size or statistical significance of the bank-level variables.

When we replace period and regional dummies with country-specific macroeconomic variables, the fit of the regression improves, with the magnitude and statistical significance of bank-level variable coefficients remaining broadly unchanged. Changes in real GDP growth are not significantly correlated with the evolution of bank profitability, and neither are those in the output gap or the unemployment level (the latter results are not reported). Not surprisingly, a stock market boom is positive for bank profits, while higher sovereign country risk measured by the spread to bunds is a negative. A widening of the deposit rate premium relative to the one-month interbank rate is also associated with declining profitability, suggesting that strong competition on the deposit side or regulation of deposit rates may have negatively affected bank profit growth.

Introducing into the specification contemporaneous changes in bank-level variables helps improve the fit of the regression, but it does not change our results concerning initial bank characteristics. While changes in the share of fee and commission income in total income do not appear to have played a role, banks which reduced reliance on wholesale funding experienced stronger profit growth (or a more limited profit decline). This suggests that banks that could reorient funding away from wholesale funding (most likely toward deposits) also protected profitability through the financial cycle, perhaps by disengaging from less profitable activities financed by wholesale funding. ${ }^{16}$ Note that in this relationship operating costs are controlled for, so that any adverse effect of a switch to deposit funding on operating costs (perhaps reflective the cost of setting up a retail network or providing other services for free to depositors to attract them) is ignored. Thus, conditional on a given level of operating costs, switching away from wholesale funding has supported bank profits. In terms of magnitude, a 5-percentage point decline in the ratio of wholesale funding to assets is associated with an increase in ROA of 8 basis points, which is a sizable effect.

Improved operating cost efficiency is also significantly associated with better profitability: lowering the ratio of these expenditures to total assets by 100 basis points is associated with an increase in profits by some $30-40$ basis points, which is a large economic effect. Another

\footnotetext{
${ }^{15}$ High profit growth in Eastern EU likely reflects the strong expansion in bank credit in the region during the boom years.

${ }^{16}$ Based on our definition, funding from central banks is included in wholesale funding, so replacing market wholesale funding with central bank funding would leave our measure unchanged. The data do not allow us to distinguish between market and central bank funding.
} 
factor affecting profitability very markedly is changes in asset quality: banks that experienced an increase in the NPL ratio of 5 percentage points saw an additional decline in ROA by more than 30 basis points based on our coefficient estimates. Interestingly, the size and statistical significance of the coefficient of NPLs do not change much whether we control for regional dummies or alternative, country-specific macroeconomic variables. This may be because macro-variables for the country of incorporation do not adequately reflect macroeconomic conditions of bank debtors, as many banks operate across borders. But it may also suggest that differences among NPL levels across banks did not simply reflect different macroeconomic circumstances but also (or mostly) bank-specific factors, such as different business strategies or credit risk-management across banks within countries.

\section{Cross-Sectional Regressions}

Next, we analyze how the various factors played out over the different phases of the financial cycle. Table 9 column (1) shows the regression from column (3) of Table 8, and columns (2), (4), and (6) replicate this specification for three separate cross-sections, capturing transitions across the four phases of the financial cycle. Because the sample composition changes over time, reflecting improved coverage of the database over time, the table also includes results for a constant (and much smaller) sample that is akin to the one used in column (2). The reduced sample regression results are shown in columns (5) and (7), respectively, for the boom-to-crisis and crisis-to-post-crisis transitions.

The first observation is that mean reversion was most pronounced in the transition from boom to crisis and from crisis to post-crisis, while it was smaller in the transition from preboom to boom. This may indicate that pre-boom and boom years were not very different in terms of factors affecting bank profitability. In contrast, banks that did well during the boom were more likely to see large profit declines in the crisis, and banks that did relatively well in the crisis were similarly more likely to see their relative good performance disappear in the post-crisis period.

The (negative) relationship between asset growth and subsequent change in profits is particularly pronounced post-crisis (though it is significant only in the larger sample). This may indicate that banks which shrank their operations more drastically during the crisis were rewarded with better profits in the subsequent years. It is broadly consistent with evidence about Italian banks in Bonaccorsi di Patti and Kashyap (2017). This study finds that banks which cut credit to problem borrowers early experienced a faster recovery in profitability than banks which continued to extend credit to such borrowers. 
Table 9. Bank Profitability Over the Financial Cycle: Cross-Sectional Regressions

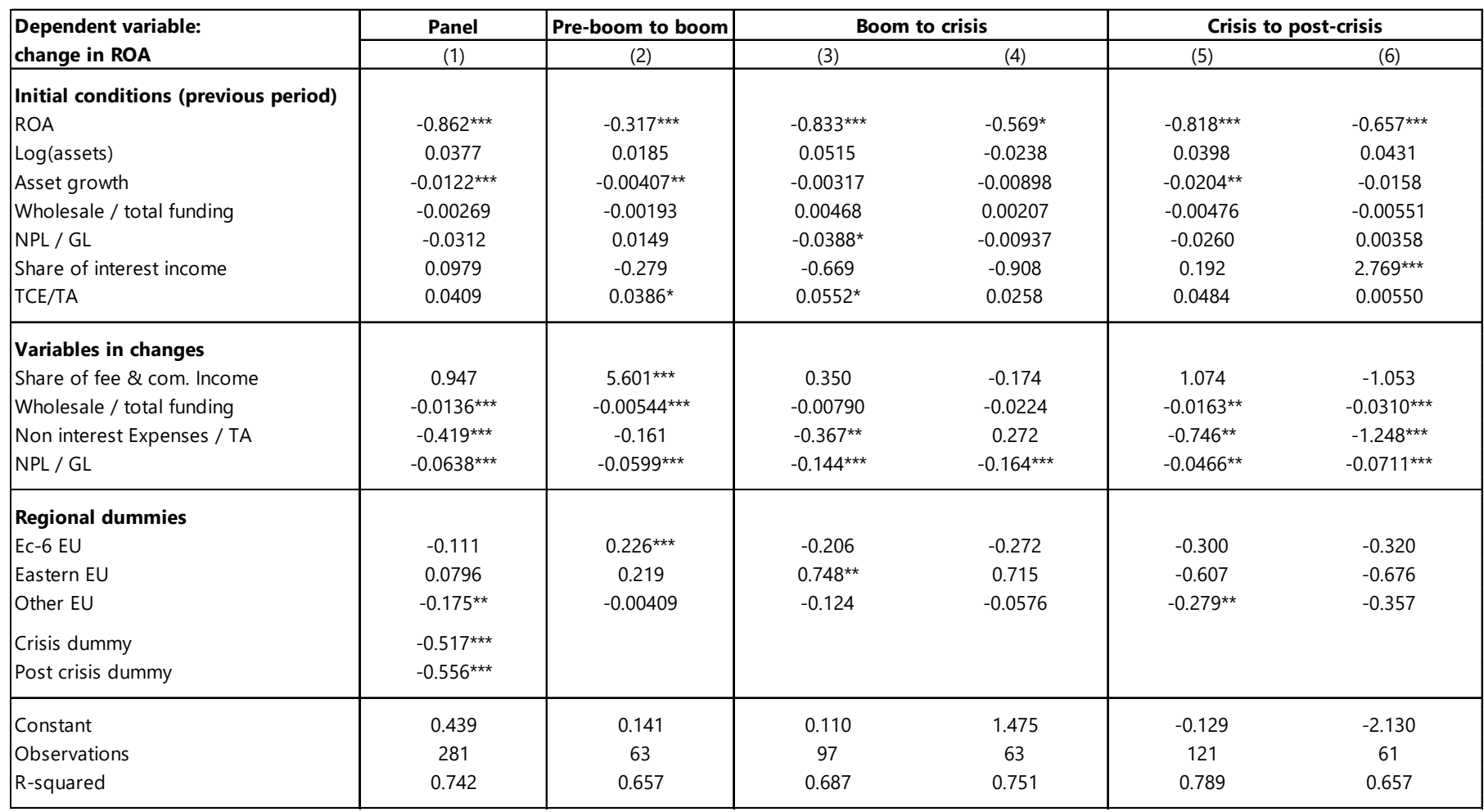

Robust standard errors in parentheses, obs. clusted at the bank level.

${ }^{* * *} p<0.01,{ }^{* *} p<0.05,{ }^{*} p<0.1$

Cost cutting and asset quality played a bigger role in protecting profitability during the crisis and post-crisis period than in the boom, not surprisingly. The regression also shows that the peak of the NPL effect on profitability occurred during the crisis period.

Finally, the positive effects of switching away from wholesale funding are mainly visible during the post-crisis period, while the coefficient is small and insignificant during the crisis. It may be that cuts in wholesale funding during the crisis were associated with fire sales, which did not help profitability, while those in the post-crisis period reflected a more deliberate and orderly business reorientation that included a shift toward cheaper or more stable deposit funding.

\section{Probit Regressions}

Next, we consider which characteristics make highly profitable banks in the post-crisis environment different from other banks. To this end, we define as highly profitable banks that fall in the top quintile of the ROE distribution during the post-crisis period. These banks had a ROE equal or higher than 9 percent, which is close to what many analysts regard as the 
cost of bank capital in the post-crisis period. ${ }^{17}$ Thus, the group of highly profitable banks comprises banks that were able to earn at least their cost of capital in more recent years. We estimate the following cross-sectional Probit model:

$$
\operatorname{Pr}\left(Y_{i j}=1 \mid Z\right)=\Phi\left(Z=\alpha+\beta X_{i, j}+\delta M_{j}+\varepsilon_{i j}\right),
$$

where the left-hand side is the probability of a bank belonging to the high profit group in the post crisis period, $\Phi$ is the cumulative distribution function of the standard normal distribution, $\alpha, \beta, \chi, \delta$ are vectors of estimated parameters and $\varepsilon$ is a residual. The set of vectors of variables $X_{i, j}$ and $M_{j}$ contain respectively bank-level variables and macroeconomic variables averaged over the post-crisis period.

Table 10 reports the findings of the Probit analysis. The country-group dummies for the EC-6 and Other EU are significant and negative, indicating that banks in these two groups were less likely to be highly profitable than Nordic banks (the residual category). Interestingly, the coefficient of the Other EU group is especially large, suggesting that banks in this group were facing especially challenging profitability conditions. When country-group dummies are replaced with macroeconomic control variables, the only factor that seems to matter is the short-term interest rate. The coefficient of this variable is positive, i.e. higher short-term interest rates make it more likely that banks achieve adequate profitability. These findings lend some support to the view that the low interest environment is a challenge to bank profitability in the post-crisis period. Even though stylized facts did not reveal sizeable declines so far in interest margins overall, too low interest rates for too long may increase such pressures going forward.

Turning to bank-specific characteristics, highly profitable banks in the post-crisis were smaller in size and had better loan quality (low ratio of NPL to gross loans) than other banks. There is also some evidence that these banks relied less on interest income as a source of revenue, although this association is not as robust across specification as those with size and NPLs. On the other hand, the funding model did not seem to matter, as reliance on wholesale funding by itself is not associated with the probability that a bank has high profitability relative to peers. This suggests that the funding model by itself is not a determining factor of the success of a bank. Moreover, the rate of asset expansion is (marginally) significant (with a negative coefficients) only in some specifications.

\footnotetext{
${ }^{17}$ See IMF (2017a), Chapter 1.
} 


\begin{tabular}{|c|c|c|c|c|c|c|}
\hline \multicolumn{7}{|c|}{ Table 10. Bank Profitability Post-Crisis: Cross-Sectional Probit Regressions } \\
\hline Probit: top $20 \mathrm{RO}$ & & (1) & (2) & (3) & (4) & $(5)$ \\
\hline \multicolumn{7}{|c|}{ Firm level explanatory variables } \\
\hline \multicolumn{7}{|c|}{ Contemporaneous firm characteristics } \\
\hline & $\log$ (assets) & $-0.193^{* *}$ & -0.136 & $-0.168^{*}$ & $-0.230 * *$ & $-0.218^{* *}$ \\
\hline & Asset growth & -0.000487 & -0.000853 & -0.00113 & $-0.00189^{*}$ & $-0.00185^{*}$ \\
\hline & NPL/GL & $-0.102^{* * *}$ & $-0.133^{* * *}$ & $-0.0911^{* * *}$ & $-0.133^{* * *}$ & $-0.131^{* * *}$ \\
\hline & share of wholesale funding & -0.00646 & -0.0111 & -0.000768 & 0.00231 & 0.00220 \\
\hline \multicolumn{3}{|c|}{ Interest income (share of gross income) -0.677} & -0.279 & $-2.597 * *$ & $-4.224 * * *$ & $-4.093^{* * *}$ \\
\hline \multirow{3}{*}{ Country groups: } & EC-6 countries & & $-0.949 *$ & & & \\
\hline & Eastern EU countries & & 0.543 & & & \\
\hline & Other EU countries & & $-1.414 * * *$ & & & \\
\hline \multicolumn{7}{|c|}{ Macro variables Post crisis averages } \\
\hline & Deposit rate - ST rate & & & -0.395 & & -0.154 \\
\hline & ST rate & & & & $0.841^{* * *}$ & 0.690 \\
\hline & Spread to Bund & & & & 0.0125 & 0.0429 \\
\hline & Constant & $2.783^{* *}$ & $3.108^{* *}$ & $4.270^{* *}$ & $5.666^{* * *}$ & $5.632^{* * *}$ \\
\hline & Observations & 129 & 129 & 127 & 121 & 121 \\
\hline
\end{tabular}

\section{CONCLUSIONS}

Using bank-level data over 2000-16, this paper has revisited the performance of EU banks during the past financial cycle. The data show that, from 2000 through 2007, EU banks went through a period of rapid balance sheet expansion, financed through a rising share of wholesale funding. The expansion was not accompanied by a commensurate increase in high-quality capital: as bank leverage rose, returns on equity were boosted, flattering the banks' bottom line. These trends were widespread across EU banks, though they were more pronounced in larger banks. The rapid expansion process went abruptly into reverse beginning in 2008, as contagion from the U.S. subprime crisis spread. As wholesale funding withered, banks downsized sharply and reduced their leverage under pressure from markets and supervisors. Deteriorating loan quality, especially in the countries hit by the euro sovereign crisis and in Eastern Europe, contributed to the difficulties. Ample liquidity support and capital injection from governments in many countries were necessary to stave off systemic losses. Even after the acute phase of the crisis ended, bank profitability remained low as banks had to operate with lower leverage, many struggled to cut costs while downsizing their scale of operation, and some remained saddled with high NPLs.

Perhaps surprisingly, we find that net interest margins remained broadly stable over the financial cycle. Interest earnings and expenses fell in lockstep during the down part of the cycle, leaving margins little changed. Thus, it appears that by and large banks passed on changes in borrowing interest rates to their customers in the form of higher lending rates. Hence, the much-discussed adverse effects of the low interest rate environment on bank profitability are not visible in our data - or at least not yet. 
Against the background of these broader trends, the paper has explored which bank-specific characteristics and behaviors helped banks better preserve their profitability in the different phases of the financial cycle. We find that several factors help explain changes in profitability, with an impact that is statistically and economically significant as well as robust. First, not surprisingly, banks that managed to contain the rise in NPLs were more successful, even after controlling for macroeconomic factors. This may indicate that differences in credit risk management across banks mattered, though also different institutional settings (e.g., insolvency frameworks, legal means to repossess collateral, etc.) and macroeconomic environment may have played a role. An interesting topic for future research would be to differentiate among these factors. Second, banks that reduced operating costs more drastically were rewarded with smaller profit declines. This confirms that cost discipline, including through consolidation through branch reduction, is important in preserving profitability over the cycle. Eastern EU and Nordic banks appeared to have been the most successful at cost reduction among the banks in our sample. Future research could usefully explore how cost reduction was achieved, whether by reductions in branch networks, faster technology adoption, containment in employee compensation, or other strategies.

A third interesting result is that banks that reduced their assets more aggressively during the crisis experienced a smaller decline in profits in the post-crisis years. This may indicate that quickly disposing of non-performing or non-core assets, though it may have a short-term cost, pays off in terms of profitability. It may also point to a macroeconomic tradeoff, as more rapid bank portfolio downsizing may lead to corporate sector insolvency through a credit crunch. A fourth finding is that reorienting funding away from wholesale markets was associated with more favorable profit developments in the post-crisis years. This may indicate that deposit funding was more advantageous in the post-crisis environment, or that such change in funding was associated with more successful business strategy reorientations.

In the post-crisis environment, banks that managed to generate a return on equity of at least 9 percent (about one fifth of the banks in our sample) were smaller and had loans of better quality on their books. We do not find a robust relationship between increased reliance on fee and commission income and improved profit performance in recent years, suggesting perhaps that traditional reliance on interest margins can still be a successful business model for banks. 


\section{References}

Acharya, V., and S. Steffen, 2014, "Falling Short of Expectations? Stress Testing the European Banking System," CEPS Policy Brief No. 315.

Alessandri, P., and B. Nelson, 2014, "Simple Banking: Profitability and the Yield Curve," Journal of Money, Credit and Banking 47, 143-175.

Bonaccorsi di Patti, Emilia, and Anil Kashyap, 2017, Which Banks Recover from Large Adverse Shocks, NBER Working Paper No. 23654.

Borio, C., L. Gambacorta, and B. Hofmann, 2015, “The Influence of Monetary Policy on Bank Profitability," BIS Working Papers, No. 514 (October).

Borio, C, 2014, "The Financial Cycle and Macroeconomics: What Have we Learnt?", Journal of Banking and Finance 45, 182-198.

Busch, R., and C. Memmel, 2015, "Bank's Net Interest Margin and the Level of Interest Rates,” Deutsche Bundesbank Discussion Paper, No. 16/2015.

Calomiris, C. and D. Nissim, "Crisis-Related Shifts in the Market Valuation of Banking Activities," Journal of Financial Intermediation 23, 400-435.

Claessens, S. N. Coleman, and M. Donnelly, 2016, "Low-for-long" Interest Rates and Net Interest Margins of Banks in Advanced Foreign Economies. Federal Reserve Board of Governors International Finance Discussion Papers Notes, April 11, 2016.

Constancio, Vitor, 2017, Challenges Faced by the European Banking Sector, speech at the Italian Banking Association, Rome, June 14.

Demirgüç-Kunt, A., E. Detragiache, and O. Merrouche, 2013, "Bank Capital: Lessons from the Financial Crisis," Journal of Money, Credit, and Banking, Vol. 45, No. 6, $1147-$ 1164. 2013.

Ennis, H., H. Fesseden, and J. Walter, 2016, "Do Net Interest Margins and Interest Rates Move Together?” Economic Brief 16-05, Federal Reserve Bank of Richmond.

European Central Bank, “Financial Stability Review,” November 2016, Euro Area Financial Institutions.

International Monetary Fund (IMF), Global Financial Stability Report, 2016a, October, Washington DC. ,2016b, France - Selected Macro-financial Issues, Country Report No. 16/228, July, Washington DC. 
, 2017a, Global Financial Stability Report, April, Washington DC.

,2017b, Spain Financial Sector Assessment Program - Technical Note:

The Determinants of Bank Profitability, December, Washington DC.

Kok, Christoffer, Csaba Móré and Cosimo Pancaro, 2015, Bank Profitability Challenges in Euro Area Banks: The Role of Cyclical and Structural Factors, European Central Bank, Financial Stability Review, pp. 134-145.

McCauley, Robert N., Agustín S. Bénétrix, Patrick M. McGuire, and Goetz von Peter, 2017, Financial Deglobalisation in Banking?, BIS Working Papers No. 650, June.

Roengpita, Rungporn, Nikola Tarashev, and Kostas Tsatsaronis, 2014, Bank Business Models, BIS Quarterly Review, December Issue, pp. 55-65.

Sarin, N. and L. Summers, 2016, Have Big Banks Gotten Safer? Brookings Papers on Economic Activity.

Turk, Rima, 2016, Negative Interest Rates: How Big a Challenge for Large Danish and Swedish Banks? IMF WP/16/198, Washington DC. 


\section{Data Appendix}

Table A1. Number of Banks by Country

\begin{tabular}{cc}
\hline Country & $\begin{array}{c}\text { Number of } \\
\text { banks }\end{array}$ \\
\hline Austria & 12 \\
\hline Belgium & 3 \\
\hline Cyprus & 2 \\
\hline Denmark & 5 \\
\hline Finland & 1 \\
\hline France & 7 \\
\hline Germany & 19 \\
\hline Greece & 4 \\
\hline Hungary & 3 \\
\hline Ireland & 3 \\
\hline Italy & 18 \\
\hline Luxembourg & 3 \\
\hline Netherlands & 5 \\
\hline Poland & 1 \\
\hline Portugal & 5 \\
\hline Romania & 1 \\
\hline Slovenia & 2 \\
\hline Spain & 7 \\
\hline Sweden & 4 \\
\hline UK & 9 \\
\hline Total & $\mathbf{1 1 4}$ \\
\hline
\end{tabular}




\begin{tabular}{|c|c|}
\hline \multicolumn{2}{|r|}{ Table A2. List of G-SIBs } \\
\hline Country & Bank Name \\
\hline China & Agricultural Bank of China \\
\hline China & Bank of China \\
\hline China & China Construction Bank \\
\hline China & Industrial and Commercial Bank of China \\
\hline France & BNP Paribas \\
\hline France & Groupe Credit Agricole \\
\hline France & Societe Generale \\
\hline Germany & Deutsche Bank \\
\hline Italy & UniCredit \\
\hline Japan & Mitsubishi UFJ FG \\
\hline Japan & Mizuho FG \\
\hline Japan & Sumitomo Mitsui FG \\
\hline Netherlands & ING Bank \\
\hline Spain & Banco Santander \\
\hline Sweden & Nordea Bank \\
\hline Switzerland & Credit Suisse \\
\hline Switzerland & UBS \\
\hline United Kingdom & Barclays \\
\hline United Kingdom & HSBC \\
\hline United Kingdom & Standard Chartered \\
\hline United Kingdom & Royal Bank of Scotland \\
\hline United States & Bank of America \\
\hline United States & Bank of New York Mellon \\
\hline United States & Citigroup \\
\hline United States & Goldman Sachs \\
\hline United States & JP Morgan Chase \\
\hline United States & Morgan Stanley \\
\hline United States & State Street Corporation \\
\hline United States & Wells Fargo \\
\hline Total & 29 \\
\hline
\end{tabular}




\begin{tabular}{|lccccc}
\hline \multicolumn{5}{|c|}{ Table A3. Initial Conditions and Changes over Time } \\
\hline & Mean & Median & Std. Dev. & Min & Max \\
\hline Variables in level & & & & & \\
ROA & 0.24 & 0.31 & 0.80 & -3.77 & 2.86 \\
Log (assets) & 11.42 & 11.25 & 1.52 & 7.18 & 14.81 \\
Asset growth & 7.68 & 1.67 & 41.08 & -34.99 & 754.69 \\
Wholesale funding / total funding & 30.90 & 27.89 & 21.11 & 0.60 & 100.00 \\
Non performing loans / gross loans & 0.00 & 3.91 & 0.00 & 0.00 & 0.00 \\
Share of interest income & 6.39 & 0.81 & 7.46 & 0.00 & 51.26 \\
Tangible common equity / total equity & 0.80 & 4.63 & 0.27 & -2.06 & 4.28 \\
Variables in change & & & & & \\
ROA & -2.85 & -0.06 & 125.10 & -1490.81 & 1470.31 \\
Fees and commission inc. / total income & 0.01 & 0.01 & 0.09 & -0.68 & 0.66 \\
Wholesale funding / total funding & -1.83 & -0.88 & 11.59 & -83.51 & 32.86 \\
Non interest expenses / total assets & -0.21 & -0.07 & 1.19 & -19.70 & 2.36 \\
Non performing loans / gross loans & 2.98 & 1.30 & 5.77 & -7.99 & 38.17 \\
\hline & & & & & \\
\hline
\end{tabular}




\begin{tabular}{|c|c|c|c|c|c|c|c|c|c|c|c|c|c|c|}
\hline \multicolumn{15}{|c|}{ Table A4. Cross-correlations } \\
\hline & \multicolumn{8}{|c|}{ Variables in level } & \multicolumn{6}{|c|}{ Variables in change } \\
\hline & ROA & ROE & $\begin{array}{l}\text { Log } \\
\text { (assets) }\end{array}$ & $\begin{array}{l}\text { Asset } \\
\text { growth }\end{array}$ & $\begin{array}{l}\text { Wholesale } \\
\text { funding / total } \\
\text { funding }\end{array}$ & $\begin{array}{c}\text { Non } \\
\text { performing } \\
\text { loans / gross } \\
\text { loans }\end{array}$ & $\begin{array}{c}\text { Share of } \\
\text { interest } \\
\text { income }\end{array}$ & $\begin{array}{c}\text { Tangible } \\
\text { common equity } \\
\text { / total equity }\end{array}$ & ROA & ROE & $\begin{array}{l}\text { Fees and } \\
\text { commission } \\
\text { inc. / total } \\
\text { income }\end{array}$ & $\begin{array}{l}\text { Wholesale } \\
\text { funding / total } \\
\text { funding }\end{array}$ & $\begin{array}{l}\text { Non interest } \\
\text { expenses / } \\
\text { total assets }\end{array}$ & $\begin{array}{c}\text { Non } \\
\text { performing } \\
\text { loans / gross } \\
\text { loans }\end{array}$ \\
\hline $\begin{array}{l}\text { Variables in level } \\
\text { ROA }\end{array}$ & 1 & & & & & & & & & & & & & \\
\hline ROE & $\begin{array}{l}0.1504 \\
0.0047\end{array}$ & 1 & & & & & & & & & & & & \\
\hline Log (assets) & $\begin{array}{c}-0.2084 \\
0.0001\end{array}$ & $\begin{array}{l}-0.0404 \\
0.4507\end{array}$ & 1 & & & & & & & & & & & \\
\hline Asset growth & $\begin{array}{c}0.6842 \\
0\end{array}$ & $\begin{array}{l}0.0648 \\
0.2339\end{array}$ & $\begin{array}{c}-0.1704 \\
0.0016\end{array}$ & 1 & & & & & & & & & & \\
\hline Wholesale funding / total funding & $\begin{array}{l}-0.1221 \\
0.0222\end{array}$ & $\begin{array}{l}-0.0416 \\
0.4374\end{array}$ & $\begin{array}{c}0.2855 \\
0\end{array}$ & $\begin{array}{l}-0.0834 \\
0.1255\end{array}$ & 1 & & & & & & & & & \\
\hline Non performing loans / gross loans & $\begin{array}{c}-0.4132 \\
0\end{array}$ & $\begin{array}{l}-0.0296 \\
0.6152\end{array}$ & $\begin{array}{l}-0.0847 \\
0.1504\end{array}$ & $\begin{array}{l}-0.1189 \\
0.0452\end{array}$ & $\begin{array}{l}-0.1747 \\
0.0028\end{array}$ & 1 & & & & & & & & \\
\hline Share of interest income & $\begin{array}{l}-0.196 \\
0.0002\end{array}$ & $\begin{array}{l}-0.0651 \\
0.2237\end{array}$ & $\begin{array}{l}0.0613 \\
0.2521\end{array}$ & $\begin{array}{l}-0.1498 \\
0.0057\end{array}$ & $\begin{array}{l}0.2674 \\
0\end{array}$ & $\begin{array}{l}-0.0086 \\
0.8835\end{array}$ & 1 & & & & & & & \\
\hline Tangible common equity / total equity & $\begin{array}{c}0.4609 \\
0\end{array}$ & $\begin{array}{l}0.0449 \\
0.4014\end{array}$ & $\begin{array}{c}-0.3735 \\
0\end{array}$ & $\begin{array}{c}0.4082 \\
0\end{array}$ & $\begin{array}{l}-0.1129 \\
0.0344\end{array}$ & $\begin{array}{l}-0.0243 \\
0.6806\end{array}$ & $\begin{array}{l}-0.1351 \\
0.0113\end{array}$ & 1 & & & & & & \\
\hline $\begin{array}{l}\text { Variables in change } \\
\text { ROA }\end{array}$ & $\begin{array}{c}-0.7173 \\
0\end{array}$ & $\begin{array}{l}-0.1557 \\
0.0035\end{array}$ & $\begin{array}{l}0.1194 \\
0.0253\end{array}$ & $\begin{array}{c}-0.5918 \\
0\end{array}$ & $\begin{array}{l}0.1005 \\
0.0599\end{array}$ & $\begin{array}{l}0.1328 \\
0.0237\end{array}$ & $\begin{array}{l}0.114 \\
0.0328\end{array}$ & $\begin{array}{c}-0.2884 \\
0\end{array}$ & 1 & & & & & \\
\hline ROE & $\begin{array}{r}-0.0677 \\
0.2055\end{array}$ & $\begin{array}{c}-0.7211 \\
0\end{array}$ & $\begin{array}{l}-0.0108 \\
0.8398\end{array}$ & $\begin{array}{l}-0.0265 \\
0.6264\end{array}$ & $\begin{array}{l}-0.0252 \\
0.6374\end{array}$ & $\begin{array}{l}0.0388 \\
0.5108\end{array}$ & $\begin{array}{l}0.0198 \\
0.7116\end{array}$ & $\begin{array}{l}0.0007 \\
0.9891\end{array}$ & $\begin{array}{l}0.1344 \\
0.0117\end{array}$ & 1 & & & & \\
\hline Fees and commission inc. / total income & $\begin{array}{l}-0.0614 \\
0.253\end{array}$ & $\begin{array}{l}-0.031 \\
0.5638\end{array}$ & $\begin{array}{l}0.0016 \\
0.976\end{array}$ & $\begin{array}{l}-0.0242 \\
0.6578\end{array}$ & $\begin{array}{l}-0.021 \\
0.6967\end{array}$ & $\begin{array}{l}0.0531 \\
0.3675\end{array}$ & $\begin{array}{c}-0.4121 \\
0\end{array}$ & $\begin{array}{l}-0.0185 \\
0.7305\end{array}$ & $\begin{array}{l}0.1073 \\
0.0454\end{array}$ & $\begin{array}{l}0.0504 \\
0.3488\end{array}$ & 1 & & & \\
\hline Wholesale funding / total funding & $\begin{array}{l}0.1972 \\
0.0002\end{array}$ & $\begin{array}{l}-0.0604 \\
0.2588\end{array}$ & $\begin{array}{l}-0.0399 \\
0.4557\end{array}$ & $\begin{array}{l}0.0563 \\
0.3012\end{array}$ & $\begin{array}{c}-0.2783 \\
0\end{array}$ & $\begin{array}{l}-0.2341 \\
0.0001\end{array}$ & $\begin{array}{c}-0.0648 \\
0.2261\end{array}$ & $\begin{array}{l}-0.1135 \\
0.0335\end{array}$ & $\begin{array}{l}-0.134 \\
0.012\end{array}$ & $\begin{array}{l}0.1198 \\
0.0248\end{array}$ & $\begin{array}{r}-0.0225 \\
0.6762\end{array}$ & 1 & & \\
\hline Non interest expenses / total assets & $\begin{array}{c}-0.6152 \\
0\end{array}$ & $\begin{array}{l}-0.0251 \\
0.6394\end{array}$ & $\begin{array}{c}0.2199 \\
0\end{array}$ & $\begin{array}{c}-0.8836 \\
0\end{array}$ & $\begin{array}{l}0.0789 \\
0.1402\end{array}$ & $\begin{array}{l}0.078 \\
0.1851\end{array}$ & $\begin{array}{c}0.2169 \\
0\end{array}$ & $\begin{array}{c}-0.5411 \\
0\end{array}$ & $\begin{array}{c}0.4453 \\
0\end{array}$ & $\begin{array}{l}0.0002 \\
0.9964\end{array}$ & $\begin{array}{l}0.0181 \\
0.737\end{array}$ & $\begin{array}{c}-0.0366 \\
0.4945\end{array}$ & 1 & \\
\hline Non performing loans / gross loans & $\begin{array}{c}-0.2261 \\
0.0001\end{array}$ & $\begin{array}{l}0.0994 \\
0.0928\end{array}$ & $\begin{array}{c}-0.1421 \\
0.016\end{array}$ & $\begin{array}{c}-0.0502 \\
0.4016\end{array}$ & $\begin{array}{c}-0.1102 \\
0.0622\end{array}$ & $\begin{array}{c}0.4242 \\
0\end{array}$ & $\begin{array}{l}0.0048 \\
0.9353\end{array}$ & $\begin{array}{c}-0.0108 \\
0.8556\end{array}$ & $\begin{array}{c}-0.2004 \\
0.0006\end{array}$ & $\begin{array}{c}-0.1172 \\
0.0473\end{array}$ & $\begin{array}{l}0.0116 \\
0.8445\end{array}$ & $\begin{array}{c}-0.1854 \\
0.0016\end{array}$ & $\begin{array}{l}0.0932 \\
0.1153\end{array}$ & 1 \\
\hline
\end{tabular}

